\title{
Nature-Based Solutions for Water Management in Peri-Urban Areas: Barriers and Lessons Learned from Implementation Experiences
}

\author{
Nancy Andrea Ramírez-Agudelo*(D), Roger Porcar Anento, Miriam Villares and Elisabet Roca \\ Institute for Sustainability Science and Technology, Campus Nord, Universitat Politècnica de Catalunya \\ BarcelonaTech, 08034 Barcelona, Spain; roger.porcar@upc.edu (R.P.A.); miriam.villares@upc.edu (M.V.); \\ elisabet.roca@upc.edu (E.R.) \\ * Correspondence: andrea.ramirez.agudelo@upc.edu
}

Received: 6 October 2020; Accepted: 20 November 2020; Published: 24 November 2020

\begin{abstract}
Nature-based solutions (NBS) are defined by the European Commission as "actions that are inspired by, supported by, or copied from nature ..." and that solve societal challenges and multiple benefits. As a result, NBS are often promoted as alternative responses that solve complex societal challenges such as watershed management, while delivering a systemic approach of multiple benefits for well-being, human health, and sustainable use of resources. Despite rising interest in NBS, further identification of experiences implementing NBS could advance our understanding of the operationalization of this comprehensive concept. For this purpose, we analyzed 35 peer-reviewed articles on implementation experiences of NBS for water management in peri-urban areas, on aspects related to (i) NBS problem-solution: water challenges, ecosystem services, scales, and types; (ii) NBS governance and management. From the insights of the analysis, this paper asks what lessons are learned, and which barriers are identified, from implementing NBS for water management in peri-urban areas? As a result, this study presents a detailed analysis of each aspect. We conclude by highlighting accountancy, monitoring, and communication as potential success factors for integration and development while diminishing the overall barrier of complexity, which leads to technical, institutional, economic, and social uncertainty.
\end{abstract}

Keywords: NBS; sustainable water management; ecosystem services; problem-solution; governance

\section{Introduction}

Societal challenges such as carbon sequestration, coastal resilience, ecosystem restoration, and watershed management underpin the need for systemic ways to address them. In this sense, nature-based solutions (NBS) enable natural processes into the technical response to address these challenges, with the aim of creating multiple benefits for society [1], well-being, human health, and the sustainable use of resources. NBS are delivering the benefits through open green spaces (e.g., urban parks), green/blue infrastructures (e.g., wetlands, river parks, rain gardens), and at a building level with elements such as green roofs or green walls. For example, addressing water challenges through NBS, i.e., flood risks, droughts, water pollution, freshwater withdrawals, or difficulties related to stormwater and urban water management, promotes the development of multifunctional landscapes, e.g., river parks that could benefit human well-being and physical and mental health. Dealing with the complex and dynamic impacts of urbanization processes and climate changes through NBS could be particularly relevant in areas that combine rural and urban dynamics, identified as peri-urban areas, peripheries, sprawls, and suburbs, among others [2].

NBS has been defined as solutions inspired and supported by nature to face societal challenges while delivering benefits that are ecological, social, and economic [3]. There are plenty of arguments 
about the concept's novelty and its operationalization within well-established concepts or 'old tools' as 'natural capital', which could limit its potential [4]. For instance, the implementation of alternative responses as NBS are 'Low Impact Development' (LID) in North America [5]; 'Water Sensitive Urban Design' (WSUD) in Australia [6]; 'Sponge City' in China; 'Sustainable Urban Drainage Systems' (SUDS) [7]; Integrated Urban Water Management (IUWM); and Edible Cities [8].

In addition, the links between NBS and other green terms framed it as an 'umbrella' concept $[1,4,9]$, an aspect that was originally coined by IUCN [10] and is commonly cited [9,11-15]. The nexus of NBS with other terms has been studied by setting out how the concepts depict a metaphor [1]. Within this framing, NBS is mainly linked to terms such as ecosystem services (ES), green infrastructure (GI), and ecosystem-based adaptation (EbA) [1]. NBS promotes a comprehensive approach to contribute to human well-being, where ES are regarded as the specific benefits that humans derive from the ecosystem functions delivered through GI, as a 'network' of natural and semi-natural areas. Similarities among these concepts are its systemic approach to challenges [16], but differentiating in the problem-solving feature. For example, some authors have established a link between other GIs and ecosystems-based adaptation EbA, arguing that $\mathrm{EbA}$ is more solution-oriented than ES [9]. Whilst $\mathrm{EbA}$ is also associated with disaster risk reduction (DRR) to argue on its response to the impacts of urbanization processes [13], and climate changes [17], i.e. NBS for flood risk reduction.

NBS is considered to be a 'European' concept [1,4,9]; after being introduced by the European Commission. NBS has been supported through a definition, prioritization areas, and financing by research and development. For the first time, NBS was mentioned by the World Bank in 2008 [4]. IUCN refers to NbS in 2009 at the United Nations Framework Convention on Climate Change (COP 15) [1,4], and was adopted in 2012 as part of the IUCN program (2013-2016) [4]. In 2015, NbS was introduced as a research area within H2020, a major source of research funding for Europe, and NBS has thus 'recently entered the scientific sphere' [4]. Scientific publications have increased significantly since 2017, led by authors with European affiliations, albeit slightly from other locations.

NBS is a compound term in which 'nature-based' describes the bond with nature and natural processes [18], and the 'solution' refers to the feature of tackling a problem by providing multiple benefits in a resource-efficient manner [3]. This idea is exposed in a review that defines NBS while exploring the two-part concept, as based on nature and the solution feature [9]. NBSs are mainly related to urban contexts, yet in their search for a resource-efficient and adaptable solution, the challenges that NBS addresses, such as sustainable water management, also pertain to rural and peri-urban areas.

Therefore, the analysis of NBS implementation in peri-urban areas as hybrid territories combining urban and rural dynamics [2], is an opportunity for advancing on the identification of the derived barriers and lessons learned. Nevertheless, peri-urban areas are subject to variability across countries and regions [19]. In its conceptualization [20]; similar concepts to peri-urban could be fringe, peripheries, suburbs, sprawls, and territories in between, among others [2,19]. In this sense, peri-urban areas are recognized as transition spaces that have some degree of intermingling of urban and rural uses [20]. This consideration highlight the pressures of urbanization processes and climate changes in local and spatial aspects such as shifts in land cover, land use, land management, and planning [19]. Also, in the socioeconomic criteria and cultural context for its demarcation [21]; where the multifunctional character of peri-urban expose changes in socio-economic aspects between stakeholders sharing the area, which could lead to some conflicts because of different perspectives or interests.

These areas expose the place-based and social dynamics of neither-rural-nor-urban territories, which could condition the potential development of NBS. First, in terms of the spatial transition, peri-urban act as urban buffer zones, surrounding the urban boundary and limited by the rural one, e.g., comprising two boundaries, an inner (urban) and an outer (peri-urban) one [21]. Second, these areas are strategically relevant to ecosystem services (ES), integrating and responding to natural and built-up dynamics by acting as a multi-functional landscape. This relevance is based on the argument of proximity to natural landscapes of biodiversity habitats, woodlands, farmlands, and built-up areas; such as urban subdivisions and transport infrastructures [21]. Third, peri-urban 
areas expose the community consensus, or the lack of it, for the support and up-take of NBS as an innovation development.

Purposely, NBS and peri-urban concepts have been used as keywords in this literature review, and the references that exposed case studies were selected as implementation experiences of 'NBS' for water management in 'peri-urban areas'. The analysis followed an outline structure (i.e., social, environmental, economic, and governance) to gather the descriptors that could be supporting the comprehensive approach of NBS. Specifically, we examined NBS as a problem-solution relating to the analysis of physical and spatial aspects, and NBS governance and management to identify the actors involved and the policy instruments supporting the implementation. What lessons learned and barriers are identified in implementing NBS for water management in peri-urban areas? This article identifies the characteristics of implementing NBS in peri-urban areas as actionable knowledge in lessons learned, and the barriers as observed limitations or negative aspects. Section 2 outlines the methodology implemented, qualitative-focused multi-methods. Section 3 describes the results as NBS: problem-solution and NBS governance and management. Section 4 presents a further discussion on the analysis and significance of the barriers and lessons learned focusing on the collected evidence that could promote an advancement on the operationalization of NBS.

\section{Materials and Methods}

Our multi-methods research is qualitative-focused and comprises a literature review in combination with, content analysis, and descriptive research. The SLR helps to collect, examine, and integrate the different scientific contributions under the keyword combination "nature-based solutions' + water + peri-urban'. An initial search of peer-reviewed articles was conducted in December 2019. Two databases have been used, Scopus and Web of Science for the search of the keywords combination. As the exclusion criteria, we used the date to limit it to sources from 2015, type to gather only articles in peer-review journals and because of language limitations, we excluded references when not written in English. As the inclusion criteria, we selected articles that explicitly expose case studies of NBS and its implementation experiences. The Systematic Literature Review (SLR) was developed with the purpose of review and analysis of 'NBS implementation', dealing with water management in 'peri-urban areas', recognizing that these terms are mainly used in the European context, while other terms are used globally for similar purposes.

A literature search using digital databases to find experiences in implementing NBS, using selected keywords presented 160 references, of which 3 references were excluded because of our lack of access or they were not written in English. Of the 157 peer-reviewed publications, we first read the title and abstract to search for the terms, "water" and "case study"; 66 references mentioned case studies and were included. The excluded 91 references were related to literature reviews, conceptual, modeling, and assessment publications. We then read the 66 articles to determine their proper fit as a case study, to conduct a more intensive review and selected 35 references (Figure 1). The examination followed an outlined structure of aspects including location, environment, economics, social dimensions, and descriptors about governance, instruments, actors involved, and its financing. To support the systematic documentation of the lessons learned and barriers highlighted in the experiences, the analysis and synthesis strategy was assisted by NVivo (Qualitative Analysis Software). In terms of the review criteria, the references excluded were out of the scope of NBS implementation; because of not using cases dealing with water or to the concept of NBS, e.g., not mentioning water in the process as input, output, or benefit, or not mentioning NBS or other green terms, such as ES, GI, EbA.

Data were gathered from 35 references published in 2016 (1), 2017 (6), 2018 (6), 2019 (15) to 2020 (7), detailed information and codes for the references are presented in Appendix A, Table A1. The references present studies in different locations, but mainly from Europe where the 'NBS concept' is promoted and funded, followed by Asia, America, Africa, and Oceania. Yet, it is acknowledged that due to the concepts used, the review is predominantly focused on European experiences. Besides, even if our 
specific search including 'peri-urban' as a criterion; some case studies are linked to urban and rural areas, reinforcing the idea of interlink among built environments, beyond the administrative borders.

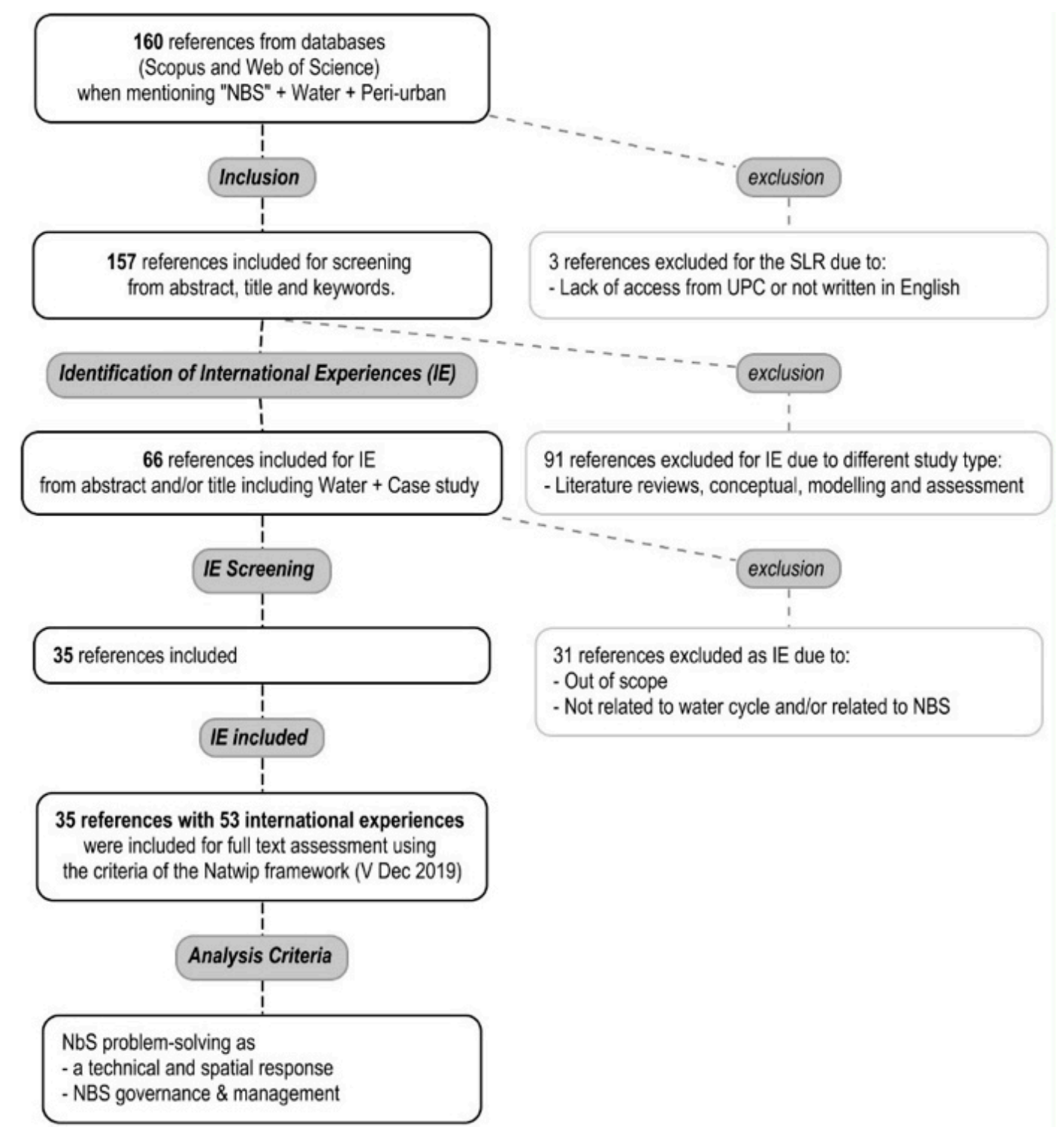

Figure 1. Literature review process.

The analysis of NBS has been structured as (i) NBS problem-solution: Water challenges, ES, types, and scales, for the technical and spatial response; and (ii) NBS governance and management, for identifying the specific factors that support NBS implementation. As our search strategy required an iterative process to determine if the case studies were included or excluded in each criterion, the case studies mentioned in each sub-section might vary. To facilitate the analysis, each aspect is included along the results using codes and references, while detailed information on each implementation experience is presented in Appendix A. The barriers and lessons learned emerged from these insights, identifying the positive descriptions in the collected evidence of the implementation as 'lessons learned' or actionable knowledge; and the negative aspects as 'barriers' or observed limitations for operationalizing NBS as a comprehensive concept. 


\section{Results}

The dominant discourse of NBS as a comprehensive approach is to achieve systemic interventions, delivering multiple benefits to multiple stakeholders in a resource-efficient manner [3]. As an integral feature of the concept, NBS link the problem addressed to the solution, within the aim of sustainable development-in other words, facing social, environmental, economic, and institutional barriers [9]. Thus, when referring to complex challenges, the aim for systemic interventions is to deliver results at different environmental-technical, and social levels. In this sense, we analyzed NBS implementation for water management to identify the specificities of the systemic response. The next sub-sections present NBS examined from two standing points. Our first search criteria aimed to examine the NBS problem-solving feature from the technical and spatial aspects (Section 3.1), responding to the ecological dimension of the concept. Second, the NBS governance and management (Section 3.2) to identify the socio-economic aspects that support NBS implementation.

\subsection{NBS Problem-Solution: Challenges, ES, Scales, and Types}

This section will explore NBS by focusing on the technical and spatial factors of NBS implementation for water challenges (Section 3.1.1), the ES delivered (Section 3.1.2), the scales of the solutions (Section 3.1.3), and types implemented (Section 3.1.4). To close this section a representation of the links among NBS types, challenges, and ecosystem services is presented. This section is complemented by Appendix A, with detailed information on each implementation experience.

\subsubsection{Challenges}

In terms of challenges, the experiences describe a variety of issues related directly and indirectly to water, reporting pressures on water resources, and the system management (Table 1). The direct challenges are flood risks, urban water systems management, freshwater withdrawals, climate regulation, freshwater supply, stormwater management, climate change mitigation and/or adaptation, water pollution purification/filtration, and drought/water scarcity. Indirect challenges are related to the effective-incorporation of socio-cultural services when mentioning concerns as recreation, human well-being, and social cohesion. See also Appendix A (Table A2).

The literature on NBS usually explains water challenges as results of the pressures from the climate influence and/or urbanization effects, and as causal mechanisms of interdependence among other challenges. This is observed, for example, on the hydrological impacts of urbanization processes, such as a reduction in perviousness, infiltration, and surface retention, which could be the causal mechanism for increasing storm rainfall going to a runoff, leading to floods [16]. Thus, flood risks are linked to stormwater management, not only by runoff and peak flows but also by conveying pollutants to nearby surface waters [17]. In this order of ideas, shifting natural landscape in peri-urban areas, towards an urbanized one, diminishes the natural land pervious cover, its infiltration, and its retention capacities. This shift could increase environmental risks, not only locally but also in other areas, which will require higher investments in infrastructure, services, and management over the long-term.

In fact, the literature frequently mentioned NBS for risk management, including floods, droughts, heatwaves, sea-level rise, and earthquakes. Figure 2 shows the relations between water challenges and risk management addressed in the literature. The thickness of the edges (nexus) are proportional to the number of articles that relate to both vertices (nodes). The strongest relations show more publications that relate risks to water challenges are 'flood', which relates to flood risk, urban water systems and pollutants purification/filtration, and "climate change" (climate change mitigation/adaptation, climate regulation and flood risk). Consequently, integrating changes in land covers and flows controls, while maintaining a certain water quality and flow, is a multi-level challenge for water management in peri-urban areas. In this sense, it is relevant to notice that water systems are also influenced by the dynamics of urban and rural systems, and decisions in other sectors as risk management. 
Table 1. Nature-based solutions (NBS) Challenges description.

\begin{tabular}{|c|c|c|c|}
\hline Challenges & Description & Codes & References \\
\hline Flood risks & $\begin{array}{l}\text { Climate change or } \\
\text { urbanization causing higher } \\
\text { occurrence of flooding }\end{array}$ & $\begin{array}{r}4,8,10,12,14,21 \\
22,23,30\end{array}$ & {$[5,7,13,17,18,22-25]$} \\
\hline $\begin{array}{l}\text { Urban water systems } \\
\text { management }\end{array}$ & $\begin{array}{l}\text { Black, gray, storm- and/or } \\
\text { freshwater management }\end{array}$ & $\begin{array}{r}7,16,20,26,32,33 \\
34,35\end{array}$ & {$[6,26-32]$} \\
\hline Freshwater withdrawals & $\begin{array}{l}\text { Related to freshwater } \\
\text { supply/withdrawals }\end{array}$ & $4,7,9,20,29,34,35$ & {$[6,25,27,28,32-34]$} \\
\hline Climate regulation & $\begin{array}{l}\text { Capacity of water bodies to } \\
\text { regulate micro-climate, e.g., } \\
\text { mitigation of urban heat } \\
\text { island (UHI) and heatwaves }\end{array}$ & $4,6,8,13,18,24$ & {$[8,13,18,25,35-37]$} \\
\hline Freshwater supply & Pollutants discharge & $25,27,28,30,32$ & {$[5,29,38-40]$} \\
\hline Stormwater management & $\begin{array}{l}\text { Created as a separate } \\
\text { category for its frequency in } \\
\text { the case studies } \\
\text { Flood prevention, runoff } \\
\text { control, drainage, } \\
\text { and filtration, etc. }\end{array}$ & $3,15,31,33$ & {$[31,41-43]$} \\
\hline $\begin{array}{l}\text { Climate change } \\
\text { mitigation and/or } \\
\text { adaptation }\end{array}$ & $\mathrm{CO}^{2}$ reduction & $12,13,18$ & {$[7,8,35]$} \\
\hline $\begin{array}{l}\text { Water pollution } \\
\text { purification/filtration }\end{array}$ & $\begin{array}{l}\text { Pollutants } \\
\text { purification/filtration }\end{array}$ & $10,11,16$ & {$[24,26,44]$} \\
\hline Drought/Water scarcity & $\begin{array}{l}\text { Related to droughts and } \\
\text { water scarcity }\end{array}$ & 22,28 & {$[13,39]$} \\
\hline $\begin{array}{l}\text { Effective-incorporation } \\
\text { of Socio-cultural services }\end{array}$ & $\begin{array}{l}\text { Includes recreational } \\
\text { opportunities, esthetics, } \\
\text { human well-being, social } \\
\text { cohesion }\end{array}$ & $1,2,5,14,17,18$ & {$[8,17,45-48]$} \\
\hline
\end{tabular}

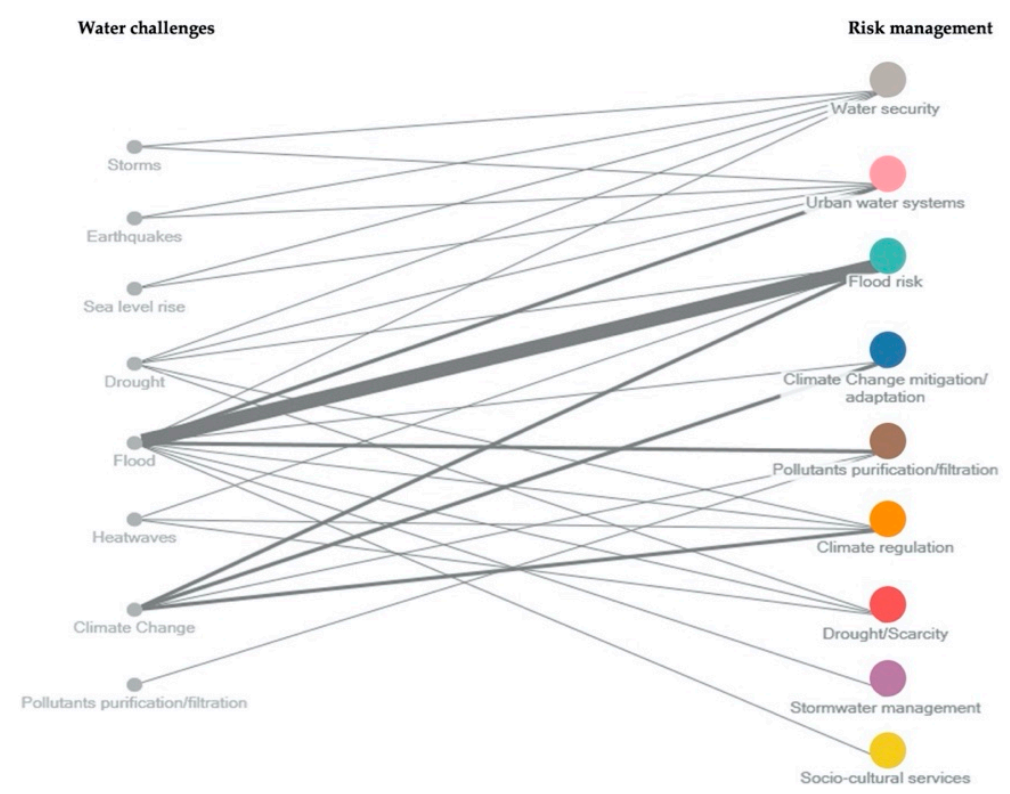

Figure 2. Relation between Water challenges (left) and Risk management (right).

\subsubsection{NBS and ES}

NBS implementation as a solution addressing, primarily, the issues related to water challenges; has the potential of delivering multiple benefits in a resource-efficient manner and adaptable manner. 
In this review, these benefits are identified through ES and its categorization of provisioning, regulating, cultural, and supporting services (Table 2). The regulating services that are frequently mentioned are the moderation of extreme events, waste-water treatment, among others. Cultural services are mainly related to recreation, mental, and physical health. Provisioning services are mainly represented through freshwater. Supporting services expose the habitat for species. See also Appendix A, Tables A3 and A4.

Table 2. Ecosystem services description.

\begin{tabular}{|c|c|c|c|}
\hline ES & Description & Codes & References \\
\hline \multirow{3}{*}{$\begin{array}{l}\text { Provisioning } \\
\text { Services }\end{array}$} & Food & $4,15,18$ & {$[8,25,42]$} \\
\hline & Raw materials & 11 & [44] \\
\hline & Freshwater & $8,9,16,22,25,27,28,32$ & {$[13,18,26,29,33,38-40]$} \\
\hline \multirow{7}{*}{$\begin{array}{l}\text { Regulating } \\
\text { Services }\end{array}$} & Local Climate Air Quality & $3,5,8,15,22,24$ & {$[13,18,36,41,42,46]$} \\
\hline & Carbon sequestration and storage & 8,22 & {$[13,18]$} \\
\hline & Moderation of extreme events & $\begin{array}{r}2,3,6,8,10,11,15,21,22 \\
23,31\end{array}$ & {$[13,18,22-24,37,41-45]$} \\
\hline & Waste-water treatment & $1,3,7,10,11,16,25,31$ & {$[24,26,27,40,41,43,44,48]$} \\
\hline & $\begin{array}{l}\text { Erosion prevention and } \\
\text { maintenance of soil fertility }\end{array}$ & 7,8 & {$[18,27]$} \\
\hline & Regulation of Water Flow & $1,4,9$ & {$[25,33,48]$} \\
\hline & Pollination & 7 & [27] \\
\hline \multirow{3}{*}{$\begin{array}{l}\text { Cultural } \\
\text { Services }\end{array}$} & $\begin{array}{l}\text { Recreation and, mental and } \\
\text { physical health }\end{array}$ & $1,2,3,5,8,10,11,15,22$ & {$[13,18,24,41,42,44-46,48]$} \\
\hline & $\begin{array}{l}\text { Aesthetic appreciation and } \\
\text { inspiration for culture, } \\
\text { art and design }\end{array}$ & $8,22,24$ & {$[13,18,36]$} \\
\hline & $\begin{array}{l}\text { Spiritual experience and sense } \\
\text { of place }\end{array}$ & 3,15 & {$[41,42]$} \\
\hline $\begin{array}{l}\text { Supporting } \\
\text { Services }\end{array}$ & Habitat for species & $1,3,7,11,15$ & {$[27,41,42,44,48]$} \\
\hline
\end{tabular}

Although, the multiple benefits and services provided through nature are recognized; the debate in the literature is more oriented to the proper assessment of these services, and its integration into different sectors, to recognize the added value of NBS. In the policy sector, advancement by the European Commission established NBS priority areas as: the regeneration and well-being in urban areas, carbon sequestration, coastal resilience, watershed management, and ecosystem restoration, to enhance the insurance value of ecosystems and to foster sustainable use of matter and energy [3].

\subsubsection{NBS Scales}

NBS implementation for water management in peri-urban areas respond to different spatial scales from site to national level (Table 3). Cases are mentioned as sites (6), neighborhood (6), municipality (20), metropolitan area (7), regional-basin level (10), and national level (1). In some cases, no explicit reference was found, thus, the category 'other' was applied (3). Implementation experiences were mainly on a municipality scale, which is associated with the level of urban planning competencies.

Despite, the spatial scale of intervention cannot address or control the overall impact of the water challenges; it is a recognition of the limits of the NBS and the need for articulated responses at different spatial scales. This shows the role of the governance level of decision-making, that the type of NBS could determine the sectors involved, and that there must be instruments allowing the required integration of governance and management for supporting NBS implementation. 
Table 3. NBS spatial scales description.

\begin{tabular}{lrr}
\hline Spatial Scale & Codes & References \\
\hline Site & $2,3,17,24,31,33$ & {$[31,36,41,43,45,47]$} \\
Neighborhood & $4,5,17,32,33,34$ & {$[6,25,29,31,46,47]$} \\
Municipality & $1,2,4,5,8,10,11,12,13,14,15,18$, & {$[5,7,8,13,17,18,24,25,28,29,34,35,39$,} \\
Metropolitan area & $19,20,22,28,29,30,31,32$ & $42-46,48,49]$ \\
Regional & $4,6,7,9,16,27,29$, & {$[25-27,33,34,37,38]$} \\
(Basin level) & $9,14,20,21,23,25,26,28,31,35$ & {$[17,22,23,28,30,32,33,39,40,43]$} \\
National & 26 & {$[30]$} \\
Other & $9,24,25$ & {$[33,36,40]$} \\
\hline
\end{tabular}

\subsubsection{NBS Types}

As technical responses, different types of NBS are presented in the implementation experiences (Table 4). NBS are wetland-related approaches, such as natural wetlands, constructed wetlands, and purpose-built wetlands (15); sustainable urban drainage systems (SUDS) (11); green-roofs/walls (11); river parks (9); agroforestry (9), parks (9); permeable pavement (4); Phytorid sewage treatment (3), which is a wastewater treatment using a specific variety of plants in constructed wetlands [13]; rain gardens (3); bioswales (2); and others (24). In this review, the solutions are differentiated elements, since there is no clear boundary between what is conceptualized as SUDS in the literature. Specifically, solutions referring to SUDS for their drainage or filtration functions could be permeable pavement, rain gardens, bioswales, green roofs, detention and retention basins, wetlands.

Table 4. NBS types description.

\begin{tabular}{lrr}
\hline NBS Types & Codes & References \\
\hline Wetlands-related & $2,4,5,10,11,12,13,14,16,18,21,25$, & $29,31,33$ \\
SUDS & {$[7,8,17,23-26,31,34,35,40,43-46]$} \\
Green-roofs/walls & $7,9,12,13,16,18,28,29,31,32,33$ & {$[7,8,26,27,29,31,33-35,39,43]$} \\
River parks & $3,8,9,12,13,15,16,18,28,29,31$ & {$[7,8,18,26,33-35,39,41-43]$} \\
Agroforestry & $4,5,9,10,11,13,16,18,29$ & {$[8,24-26,33-35,44,46]$} \\
Parks & $5,7,9,13,16,18,28,29,30$ & {$[5,8,26,27,33-35,39,46]$} \\
Permeable pavement & $5,7,8,9,13,16,18,29$ & {$[8,18,26,27,33-35,46]$} \\
Phytorid sewage treatment & $3,8,12,31$ & {$[7,18,41,43]$} \\
Rain garden & $8,22,25$ & {$[13,18,40]$} \\
Bioswales & $8,31,33$ & {$[18,31,43]$} \\
Others & 12,31 & {$[7,43]$} \\
& $1,2,3,4,6,7,8,9,17,19,20,21,22$, & {$[5,6,13,18,22,23,25,27-33,36-38,40$,} \\
& $23,24,25,26,27,30,31,32,33,34,35$ & $41,43,45,47-49]$ \\
\hline
\end{tabular}

NBS are not implemented independently but are combined within hybrid approaches of green, blue, and/or gray infrastructures. NBS as place-based interventions shift the approach to landscape management, compared to traditional infrastructural projects. This is done by emphasizing the link among the green (vegetation), and blue (floodable areas, water) areas; and the influence of changes in land covers, and land uses. To illustrate this aspect using flood risk management, some publications claim that the hybrid approach is the most widely used, followed by a green approach and then by a blue approach [50]. In contrast, others argue that the green approach, represented as a green storage, is modified and influenced by land cover and land-use change; thus, it is more vulnerable than the blue approach [23]. Despite its vulnerability, NBS propose a shift from the design and use of gray flood control infrastructure or NBS planning for water management [7].

In addition, other types of NBS could be regarded as linked to natural landscapes or to build-up landscapes (Table 5). The first solutions refer to integrating soil, vegetation, floodable areas, and water, while the latter is related to vegetation, floodable areas, and water. 
Table 5. NBS Types and Landscapes.

\begin{tabular}{|c|c|c|c|c|}
\hline & Soil & Vegetation & Floodable Areas & Water \\
\hline Built-up & & Street trees & $\begin{array}{c}\text { Retention/detention } \\
\text { basins }\end{array}$ & Ponds \\
\hline $\begin{array}{c}\text { Natural } \\
\text { Landscapes }\end{array}$ & Wildlife crossings & $\begin{array}{c}\text { Private gardens } \\
\text { Riparian corridors } \\
\text { Coastal vegetation } \\
\text { Forests }\end{array}$ & $\begin{array}{c}\text { Drainage corridors } \\
\text { Semi-natural } \\
\text { waterways } \\
\text { Floodplains }\end{array}$ & $\begin{array}{c}\text { Wet meadows } \\
\text { Other water bodies }\end{array}$ \\
\hline
\end{tabular}

To close this sub-section, NBS is represented (Figure 3) as a simplified scheme flowing from problems or challenges (left) towards a response delivering benefits (right). In the literature, the analysis of the ES supports how NBS might deliver reinforced benefits through several and simultaneous ES. Thus, this scheme exposes the problem-solving feature in the spatial and technical aspects of the NBS, as the response addressing the interconnected water challenges and delivering a multiplicity of services; rather than establishing a causal link for a fixed categorization. See also Appendix A, Tables A5 and A6.

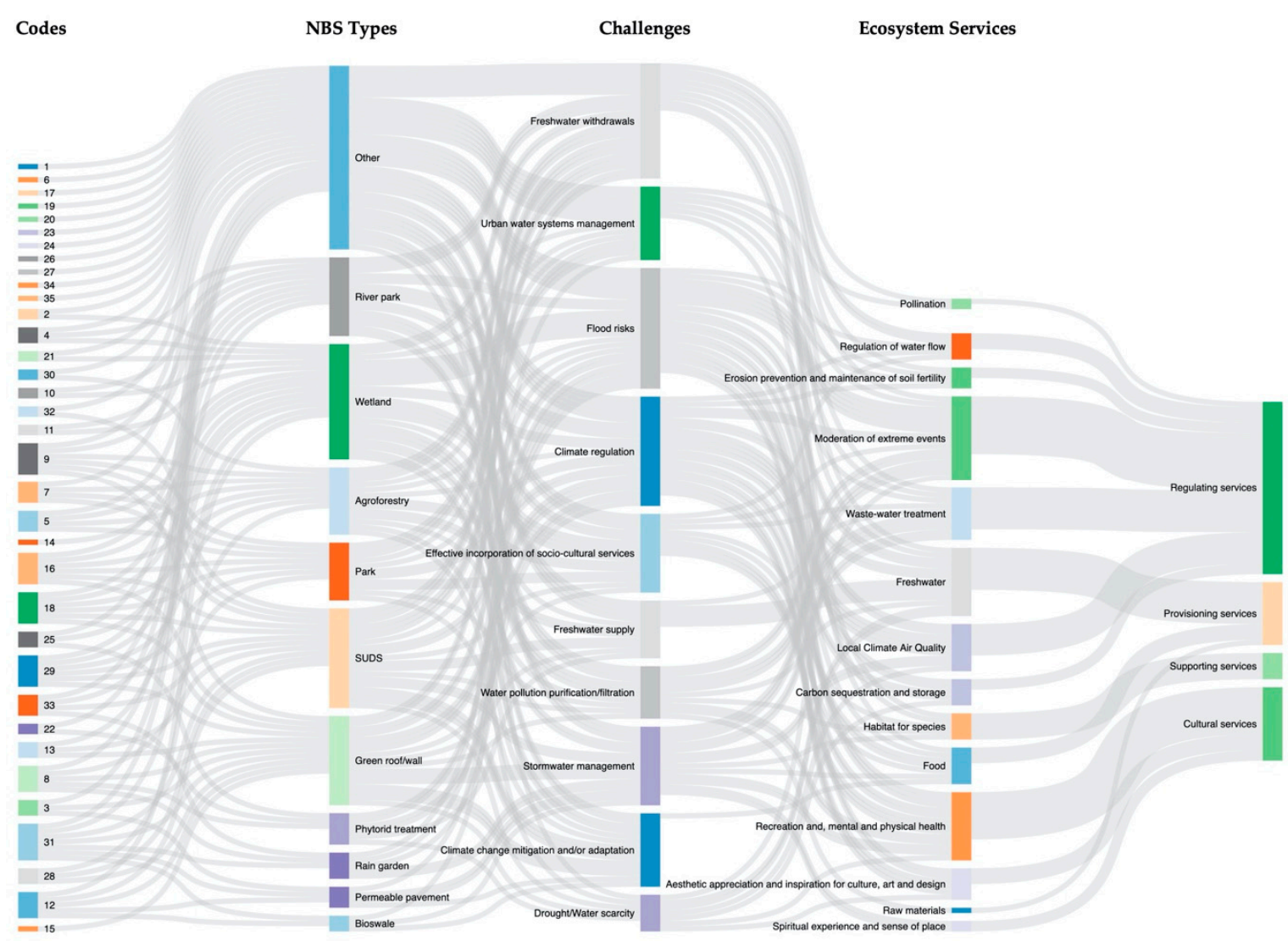

Figure 3. NBS types, challenges, and ecosystem services.

\subsection{NBS Governance and Management}

This section continues the analysis of NBS by identifying the governance and management factors that are supporting NBS implementation in peri-urban areas as the policy instruments (Section 3.2.1), the involvement of stakeholders (Section 3.2.2), and financing (Section 3.2.3). This section is complemented by Appendix A, Table A7 with detailed information on each implementation experience. 


\subsubsection{Policy Instruments}

Most of the implementation experiences mentioned some kind of policy instrument (27) supporting its implementation, such as projects, programs, and plans (Table 6). When analyzing the governance level of these instruments, the regulations could link supra-national regulations to national, regional, or municipal initiatives. Most instruments correspond to local regulations and initiatives at the municipal level, which complements the findings of the spatial scale of the projects (See Section 3.2.2). In the European Union context, the multi-level link is often developed under the EU Water Framework directive, which exposes the vertical coordination or agreement on NBS implementation. In addition, these regulatory frameworks cover long-term and cross-sectoral agendas, such as Sustainable Development Goals (SDGs); and sectoral documents, such as water planning, water management, risk management, and urban planning, displaying the interrelation among sectors for NBS while promoting specific supporting tools.

Table 6. Policy instruments mentioned.

\begin{tabular}{|c|c|c|c|c|}
\hline Level & Policy Instrument & Scale & Codes & References \\
\hline \multirow{7}{*}{ International } & \multirow{7}{*}{$\begin{array}{l}\text { Sendai Framework for Disaster Risk } \\
\text { Reduction (2015-2030) } \\
\text { Kyoto protocol } \\
\text { WaterWorld Policy Support System } \\
\text { UNESCO Biosphere Reserve" } \\
\text { protection } \\
\text { UNESCO Groundwater resource } \\
\text { sustainability indicators } \\
\text { UN's SDG } 17 \\
\text { UNICEF Joint Monitoring Program }\end{array}$} & Global & 22 & [13] \\
\hline & & Global & 13 & [35] \\
\hline & & Global & 21 & [23] \\
\hline & & Global & 2 & [45] \\
\hline & & Global & 26 & [30] \\
\hline & & Global & 20,27 & {$[28,38]$} \\
\hline & & Global & 27 & [38] \\
\hline \multirow{7}{*}{ EU Directives } & \multirow{7}{*}{$\begin{array}{l}\text { EU Water Framework Directive } \\
\text { (2000/60/EC) } \\
\text { EU Flood Directive (2007/60/EC) } \\
\text { EU FP7 -Demonstrating Ecosystem } \\
\text { Services Enabling Innovation in } \\
\text { the Water Sector (DESSIN) } \\
\text { EU Biodiversity Strategy for } 2020 \\
\text { EU Strategy on Adaptation to Climate } \\
\text { Change" (2013) } \\
\text { 6th Research Framework Program of } \\
\text { the EU }\end{array}$} & Regional & $1,10,11,14$ & {$[17,24,44,48]$} \\
\hline & & Regional & 14 & [17] \\
\hline & & & & \\
\hline & & Regional & 1 & [48] \\
\hline & & Regional & 7 & [27] \\
\hline & & Regional & 13 & [35] \\
\hline & & Regional & 30 & [5] \\
\hline \multirow{3}{*}{ Laws/Policies } & \multirow{3}{*}{$\begin{array}{l}\text { Green Highways Policy (2015) } \\
\text { Regional law (R.R. n.3 from } 24 \\
\text { March 2006) } \\
\text { Act No. 17/1992, Collection of Laws, } \\
\text { On the Environment }\end{array}$} & National & 22 & [13] \\
\hline & & Regional & 10,11 & {$[24,44]$} \\
\hline & & National & 13 & [35] \\
\hline \multirow{6}{*}{ Plans } & $\begin{array}{l}\text { River basin management plan from } \\
\text { Autorità di Bacino del Fiume Po }\end{array}$ & Sub-national & 10,11 & {$[24,44]$} \\
\hline & $\begin{array}{l}\text { Barcelona's Green and Biodiversity } \\
\text { Plan (2012-2020) }\end{array}$ & Municipal & 19 & [49] \\
\hline & Air Quality Plan (2011-2015) & Municipal & 19 & [49] \\
\hline & \multirow{3}{*}{$\begin{array}{l}\text { Finger Plan (1947) } \\
19 \text { different Canadian urban or } \\
\text { city plans } \\
\text { Italian National Plan of Adaptation to } \\
\text { Climate Change (PNCC, 2016) }\end{array}$} & Municipal & 2 & [45] \\
\hline & & Municipal & 29 & [34] \\
\hline & & National & 9 & [33] \\
\hline
\end{tabular}


Table 6. Cont.

\begin{tabular}{|c|c|c|c|c|}
\hline Level & Policy Instrument & Scale & Codes & References \\
\hline & $\begin{array}{l}\text { Action Plan for Adaptation to } \\
\text { the Adverse Effects of Climate Change } \\
\text { on Territory, the Capital City of } \\
\text { the Slovak Republic Bratislava, } \\
2017-2020\end{array}$ & Municipal & 13 & [35] \\
\hline & $\begin{array}{l}\text { The Woodlands Masterplan } \\
\text { (citing McHarg, 1970s) }\end{array}$ & Municipal & 30 & [5] \\
\hline & $\begin{array}{l}\text { River Basin Catchment } \\
\text { Management Plans }\end{array}$ & Sub-national & 16 & {$[26]$} \\
\hline \multirow{8}{*}{ Programs } & $\begin{array}{l}\text { Support Program for the Natural Area } \\
\text { of Integrated Management of Rio } \\
\text { Grande (ANGIRG) }\end{array}$ & Municipal & 28 & {$[39]$} \\
\hline & $\begin{array}{l}\text { Secretariat of the Pacific Regional } \\
\text { Environment Program (SPREP) }\end{array}$ & Regional & 35 & [32] \\
\hline & $\begin{array}{l}\text { China Major Science and Technology } \\
\text { Program for Water Pollution Control } \\
\text { and Treatment }\end{array}$ & National & 25 & {$[40]$} \\
\hline & $\begin{array}{l}\text { One Water Supply, Sanitation and } \\
\text { Hygiene (WASH) National Program } \\
\text { (OWNP) }\end{array}$ & National & 32 & [29] \\
\hline & Kibera Public Space Project (KPSP) & Municipal & 33 & [31] \\
\hline & NAIAD Project & Municipal & 14 & {$[17]$} \\
\hline & $\begin{array}{l}\text { Pacific Ecosystem-based Adaptation } \\
\text { to Climate Change (PEBACC) }\end{array}$ & Regional & 35 & {$[32]$} \\
\hline & $\begin{array}{l}\text { Joint Innovative and Technological } \\
\text { Research Projects from the Ministry of } \\
\text { Science and Technology of } \\
\text { the People's Republic of China }\end{array}$ & National & 25 & {$[40]$} \\
\hline \multirow{13}{*}{ Others } & $\begin{array}{l}\text { Mapping and Assessment of } \\
\text { Ecosystems and their Services (MAES) }\end{array}$ & Regional & 7 & {$[27]$} \\
\hline & $\begin{array}{l}\text { Jawaharlal Nehru National Urban } \\
\text { Renewal Mission (JNURM) }\end{array}$ & National & 22 & [13] \\
\hline & $\begin{array}{l}\text { Atal Mission for Rejuvenation and } \\
\text { Urban Transformation (AMRUT) }\end{array}$ & National & 22 & [13] \\
\hline & Greening the West initiative (GTW) & Municipal & 34 & [6] \\
\hline & $\begin{array}{l}\text { Community-Scale Green } \\
\text { Infrastructure (CSGI) }\end{array}$ & Local & 17 & [47] \\
\hline & Piano paesaggistico regionale (PPR) & Sub-national & 8 & [18] \\
\hline & $\begin{array}{l}\text { Piano di governo del territorio } \\
\text { (PGT, 2012) }\end{array}$ & Municipal & 8 & {$[18]$} \\
\hline & $\begin{array}{l}\text { Municipal Natural Assets } \\
\text { Initiative (MNAI) }\end{array}$ & Municipal & 29 & {$[34]$} \\
\hline & Peri-urban Land Use & & & \\
\hline & $\begin{array}{l}\text { Relationships-Strategies and } \\
\text { Sustainability Assessment Tools for } \\
\text { Urban-Rural Linkages (PLUREL) }\end{array}$ & Regional & 30 & {$[5]$} \\
\hline & $\begin{array}{l}\text { Conservation Design for Subdivisions: } \\
\text { A practical guide to create open space } \\
\text { networks }\end{array}$ & Local & 30 & [5] \\
\hline & $\begin{array}{l}\text { UK National Ecosystem } \\
\text { Assessment (2014) }\end{array}$ & National & 16 & [26] \\
\hline & $\begin{array}{l}\text { Multifold instruments (mentioned for } \\
\text { different cases) }\end{array}$ & Municipal & 18 & {$[8]$} \\
\hline
\end{tabular}




\subsubsection{Involvement of Stakeholders}

In NBS development, complex societal challenges reveal the efforts of different actors (Table 7). However, a key aspect of its implementation is the cooperation between stakeholders to address sectoral barriers, fragmentation at different governance levels, and multidisciplinary consensus. In terms of stakeholders, the categories implemented correspond to representatives of public authorities, academics and researchers, the business and private representatives, the citizens and community, including NGOs, and other water-related actors. In our review, academic and public authorities were the most mentioned actors in the case studies reviewed in this study (22), followed by the civil society (16), water-related actors (10), and business and private representatives (5).

The public sector is leading the NBS implementation effort to address the challenges described, and it takes on technical and economic leading roles. Scientific interest is reflected in the effort when research opportunities are available. The involvement of private actors and industry depends on the development of business models. The role of citizens is related to users and recipients of the benefits. However, a limitation of this study is that only peer-reviewed publications in scientific databases were considered, which may explain also the importance of the academic actors. Accordingly, further research could include the analysis of other literature sources, to complement the actors and roles.

The articles exposed different social and/or cultural values when implementing NBS. Whilst some case studies (16) involved the civil society, only one-third of them (10) explicitly mentioned its role: in the participatory process [32]; participatory modeling [17]; and personal interviews and collective meetings [41]. Also, cultural values were mentioned with terms such as recreation $[13,18,24,41,42,44-46,48]$; aesthetics [13,36,48]; social cohesion [42]; educational and therapeutic activities [47]; and cultural and historical heritage [18]. Local knowledge was slightly mentioned in educational activities [24]; [22], in activities to increase awareness [44]; and in bottom-up initiatives [31].

\subsubsection{Financing NBS}

For financing, almost half of the studies in the reviewed literature mentioned sources (Table 8). NBS is mostly funded by the public sector (14), the private sector (9), and few mentioning public-private partnerships (6). Public funding comes from local governments (municipalities), regional governments, ministries or departments of national governments or supranational institutions, such as the European Union. Research funding at the supranational level is a key aspect of this European context. Private funding comes mainly from sources such as foundations, non-profit organizations, and private corporations; or by conducting before-after simulations [43,48].

NBS has been developed as an amenity supported by public interest or through a non-profit aim, rather than through specific business models. The lack of identification of innovative business models behind NBS, reveals an open arena for identifying who is involved in the development of NBS for water management, and which roles they play. Although some references mentioned aspects related to the economic feasibility of NBS, specifically through aspects as life-cycle costs, cost-benefit analysis, or operating and maintenance costs, there were not included as part of this study; but, it should be covered in research by others. In fact, the economic feasibility of NBS is a barrier in its implementation, especially for avoiding uncertainty in its operationalization. 
Table 7. Actors mentioned in the case studies.

\begin{tabular}{|c|c|c|c|}
\hline Actors & Description & Codes & References \\
\hline Public authorities & $\begin{array}{l}\text { Local governments (municipalities, } \\
\text { planning authorities, etc.), regional } \\
\text { governments, ministries or departments, } \\
\text { national governments or even } \\
\text { supra-national institutions. }\end{array}$ & $\begin{array}{r}2,7,8,9,10,11,13,14,15,16,18 \\
19,22,25,26,28,29,30,32,33 \\
34,35\end{array}$ & {$[5,6,8,13,17,18,26,27,29-35,39,40,42,44,45,49,51]$} \\
\hline Civil society & $\begin{array}{l}\text { Citizen associations, community groups, } \\
\text { advocacy organizations, environmental } \\
\text { associations, friend groups, volunteers, } \\
\text { NGOs, etc. }\end{array}$ & $\begin{array}{r}7,10,11,13,14,15,16,17,18,22 \\
28,29,32,33,34,35\end{array}$ & {$[6,8,13,17,24,26,27,29,31,32,34,35,39,42,44,47]$} \\
\hline $\begin{array}{l}\text { Academic and research } \\
\text { bodies }\end{array}$ & $\begin{array}{l}\text { Scientific and technical experts, } \\
\text { consultants, university departments, } \\
\text { research groups, etc. }\end{array}$ & $\begin{array}{l}1,3,4,6,7,8,9,10,11,12,13,15 \\
18,20,21,22,23,25,26,27,28,31\end{array}$ & {$[7,8,13,18,22-25,27,28,30,33,35,37-44,48]$} \\
\hline Water-related actors & $\begin{array}{l}\text { Water management authorities, } \\
\text { water utilities, hydro-geologists, } \\
\text { water-sources investors, etc. }\end{array}$ & $3,5,10,11,22,25,26,27,32,34$ & {$[6,13,24,29,30,38,40,41,44,46]$} \\
\hline $\begin{array}{l}\text { Industry, business and } \\
\text { private sector }\end{array}$ & $\begin{array}{l}\text { Private landscaper, wastewater } \\
\text { treatment companies, water vendors, etc. }\end{array}$ & $5,15,16,22,26$ & {$[13,26,30,42,46]$} \\
\hline
\end{tabular}

Table 8. Funding sources mentioned in the case studies.

\begin{tabular}{llr}
\hline Financing Source & Countries & \multicolumn{1}{c}{ Codes } \\
\hline \multirow{3}{*}{ Public sector } & Italy, Poland, Slovakia; Slovenia, United & \\
& Kingdom, Spain, China, India, Ethiopia, & $8,10,11,13,14,16,19,22,25,32,34,35$ \\
& Tanzania, Australia, Vanuatu & \\
Private sector & Italy, Poland, Slovakia, Spain, China, & $10,11,13,19,22,28,32$ \\
& India, Bolivia, Ethiopia, Tanzania & $16,13,17,18,24,26,29,32,35,40,44,49]$ \\
Public-Private partnerships & Italy, Poland, Slovakia, India, China, & $10,11,13,22,26,32$ \\
\hline
\end{tabular}


In summary, the results in this section indicate that implementation experiences of NBS in peri-urban areas are addressing different challenges, at different spatial scales, but mainly at the municipal level, and are executed through several types as hybrid approaches. The governance and management aspects of the cases suggest that NBS is linked to municipal, metropolitan and regional basin scales, i.e., by interventions across administrative borders, and delivered through agreements and consensus supported by policy instruments. The recognition of the actors involved indicates the leading role of public authorities, although, in some cases, other actors as academia and industry are involved. Funding schemes executed by privates are rarely mentioned. Finally, the implementation of NBS could be considered a process of a participatory nature. NBS as a socio-technical innovation needs to advance in the economic aspects. As a further barrier, none of the case studies examined referred to the gender perspective, which could be seen as a knowledge gap in sustainable development and the NBS-well-being relationship. The next section, therefore, moves from these insights on to discuss the barriers and lessons identified.

\section{Discussion}

This paper analyzes NBS for water management in peri-urban areas, using peer-reviewed literature on the implementation experiences, with a detailed view on specific spatial and technical aspects; and more general information on the governance, and management aspects. It supports in particular a previously cited barrier of NBS: there is still a need for NBS to be operationalized to be able to collect evidence on its effectiveness [16]. The added value of NBS in terms of measuring the technical performance is presented in the literature through the recognition of ES, although, the debate is more oriented on the assessments, classifications, and scenario planning. In this review, the added value of NBS in the management and governance focused on the policy instruments and involvement of stakeholders, and economic aspects are only examined by the funding sources; but is an aspect to be researched by others, since it is equally relevant for informed cost-benefits, assessments on life-cycle costs, or operating and maintenance costs.

What lessons were learned, and which barriers were identified, by implementing NBS for water management in the peri-urban?

\subsection{Lessons Learned}

Water challenges expose pressures due to climate, risks, and urbanization. These challenges are interdependent, dynamic, and linked to the quality and quantity of the resource, revealing the complexity of water management in peri-urban areas. A common aspect is addressing water challenges through a mix of green/blue, green/gray, and green/blue/gray infrastructure approaches. NBS in the peri-urban area ranges from macroscales, such as river basins and agroforestry, to buildings as a microscale. Although there is not a fixed spatial scale, it is understood that peri-urban areas could tend to municipal levels for their planning competencies or bigger scales for implementations linking rural and urban systems. The multiple benefits delivered could be regarded as interrelated services, influencing different fields as landscape management; risks and climate regulation; recreation, physical and mental health, and well-being [35]. This approach is open to contextualization as various GI and ES are mentioned when referring to implementation experiences, e.g., in the use of NBS or other green terms such as GI, ES, Eb; also, its open to adaptation, since NBS could be known under other terms such as LID, WSUD, SUDS, IUWM.

NBS deliver structural physical changes, exposed as spatial elements enhancing water management in different material manners while being resource-efficient. These changes result from integrating different fields, instruments, and mechanisms to promote shifts in the practices of cross-sectoral expertise, e.g., infrastructure design and water management. These new practices shift different domains, for example in landscape management [11], to support built-up landscapes or natural landscapes; as well as improvements in the spatial resources, risk management, and social well-being. Specific examples are the identification of flood-prone areas and influencing factors for flood occurrence, 
such as distance, slope, and land cover [22]; design green infrastructure for increasing awareness of previously unnoticed natural features, such as sudden incidental nature experiences [45]; and improve multi-functionality of the urban green space [41].

NBS as an alternative practice, to enhance the dominant culture of gray infrastructure with interventions and experiments of blue and green approaches, could increase the potential of a peri-urban area to support human well-being. NBS implementation can deliver multiple benefits at multiple aspects; depending on the involvement and support of different levels of responsibility, territorial scales, and sectors. The operationalization of NBS could be enhanced by developing frameworks for capturing its comprehensive approach, considering it as a process, and including the multiple dimensions of its solution (e.g., spatial, technical, ecological, social, economic, etc.).

Finally, accountancy on the multi-functionality and the benefits delivered could be a critical success factor to involve cross-disciplinary approaches into NBS for water management. In this sense, monitoring NBS as a process is crucial for integrating the different scales of NBS: the spatial scale of the implementation, the scale of the challenge, and the scale of the impacts. Besides, communication about NBS could support the involvement of different actors, and the integration of sector, at different levels of decision-making to improve infrastructure planning and assessments of multiple benefits.

\subsection{Barriers}

NBS cannot control the overall impact of water challenges [32], nor can it meet all needs (e.g., high runoff volumes, high contaminant loads, etc.), that could be related to high technical uncertainty [43]. To avoid uncertainty, systemic implications of NBS require taking into account the benefits, services, and the potential risks or unintended consequences of their up-take [14]. Limitations to this purpose could be financial but could also extend to the lack of technological capacity or deficiency in infrastructure, as shown by the region-wide gap in groundwater monitoring systems and data [38]; or that affect institutional capacity [29,31]. These also affect the NBS market uptake and the creation of alternative business models and practices that support it, and thus, limiting partnerships and involvement. For instance, market uptake of NBS benefits as a field still requires legal regulations [8].

Even if NBS implementation involves different stakeholders, the promoting role is mainly done, and funded, by the public sector. The lack of interactions among the different actors involved compromises the perception of NBS, which could be negative for aspects such as costs, benefits in the short- and long-term, and impact of the solution [52]. This could lead to difficulties due to inhabitant resistance to changes [29,35], passive involvement, and insignificant increase of social cohesion [8], fear of the unknown, and uncertainty $[16,17]$. Some NBS functions could lead to disservices, which are perceived negatively or affect safety perceptions, i.e., fire risks on green spaces or drowning risks in SUDS [31]. In this sense, the cases revealed how social dynamics in terms of behavior and practices are shaped through socio-cultural values, traditions, and perceptions [16,31]; and how they influence the uptake and use of NBS [26]. Study cases revealed that NBS increases individual and public awareness for lifestyle shifts [8]. Major aspects to consider for precaution in implementing NBS are displacement, gentrification commodification, social justice regarding access to nature and human well-being, among others $[1,11,16]$.

A common aspect of the lessons learned and barriers is the knowledge demand, associated with the NBS uptake or decision-making for long-term and co-benefits [16], and on its effectiveness for comparison to conventional approaches. Therefore, NBS as a process should also be open to monitoring, i.e., for its maintenance and operation, and for examining ES and disservices. A crucial factor is to account for NBS perceptions throughout its implementation, e.g., costs, benefits; while acknowledging that both positive and negative perceptions need to be managed [52].

Limitations of this review are related to the use of European promoted terms; the lack of economic aspects related to cost-benefits, maintenance, and operation, and that none of the case studies examined referred to the gender perspective, which could be seen as a knowledge gap in the NBS-well-being 
relationship. To provide greater insight into the novelty and comprehensive approach of NBS, further research could work on these gaps.

\section{Conclusions}

NBS address different water challenges, produced by urbanization processes, changes in climate, and risks while allowing the delivery of other services. Through a systematic review, in combination with content analysis, and descriptive research, this study examined 35 articles of experiences with NBS implementation in peri-urban areas. The review presented NBS from two standing points, first from the spatial scale and technical aspects of its problem-solving feature, to respond to the ecological dimension of the concept. Second, from the governance and management, to identify the socio-economic factors that support its implementation.

Based on the insights of this analysis, we identified lessons learned and barriers. Mainly, accountancy, monitoring, and communication could be a potential success factor in NBS for water management. In this sense, accountancy to involve cross-disciplinary approaches on the multi-functionality and the benefits delivered. Monitoring on NBS as a process for integrating the different scales of NBS: the spatial scale of the implementation, the scale of the challenge, and the scale of the impacts. Communication about NBS could help to implicate different actors at different levels of decision-making. In a second order, this work identified that NBS could deliver multiple benefits, regardless of the type, scale, and location. However, in its implementation as a systemic response, its benefits are usually acknowledged as ES, which are integrated at multiple spatial scales and social aspects beyond the green infrastructure (GI). Since NBS cannot meet all needs, neither control the overall impact of water challenges, its implementation should be supported on different levels of responsibility, territorial scales, and sectors. This means that physical changes in water management should be supported on social consensus established among different stakeholders, sectors, and organizations.

Yet, a major barrier for NBS implementation is the complexity of a comprehensive approach, which leads to technical, institutional, economic, and social uncertainty. Limitations could be the lack of technological capacity or deficiency in infrastructure, as shown by the region-wide gap in groundwater monitoring systems and data [38]. Even if public authorities are playing a vital role in the promotion of NBS, by funding it, promoting research and policies; limitations could be related to the institutional capacity [29,31]; and extend to economic aspects, e.g., to promote legal regulations required for the market uptake of NBS benefits [8]. This weakness in the creation of alternative business models and practices could restrain partnerships and the support of NBS by private actors. Further NBS uptake is depending on the enhancement of technical, institutional, and financial capacities, but also on the involvement of the different actors, including lay citizens. In fact, the interaction between the different actors involved could promote greater advances to actionable knowledge, perspectives, and discourses on this solution.

Nevertheless, the effort in identifying the systemic implications of NBS, in terms of benefits, services, potential risks, and unintended consequences aids to manage the negative perceptions around NBS implementation, which could be an advancement for overcoming alternative practices as NBS. In this sense, water management requires addressing its related challenges and social aspects in an integrated way. The cases reviewed have implemented NBS as an environmental and socio-technical system, which provides a feasible approach to managing water challenges and their associated pressures. As our research focused on NBS for water management in peri-urban areas, it is limited in identifying meaningful influential factors among NBS types, ES, or built-up context. Water management in peri-urban areas could be further explored to understand the influence of urban boundaries on NBS types.

As a systematic review, this paper has different limitations. First, 'NBS' and 'peri-urban' terms used in inclusion criteria are mostly used in Europe. Although, other relevant experiences may be found under similar concepts for NBS such as LID, WSUD, SUDS, IUWM, or to peri-urban areas as suburbs, fringe, peripheries, suburbs, sprawls, etc. Second, the literature selected only covered 
peer-reviewed articles, and there may be significant evidence of experiences, lessons, and barriers, in other bodies of literature as NBS is in the intersection of science-policy-innovation. Third, our analysis has a wide-spread view of the implementation of NBS reported in the scientific literature, which usually focuses deeply on a specific discipline, therefore further analysis could advance in the operationalization of NBS in terms of frameworks for capturing its comprehensive approach. Further analysis could contrast this 'NBS in peri-urban areas' to other bodies of literature, including other terms, and explore this alternative approach from complementary concerns as the economic aspects (e.g., cost-benefits, life-cycle costs, operating and maintenance costs).

Despite these limitations, this review offers a widespread overview of the comprehensive approach of NBS regarding implementation experiences of NBS for water management in peri-urban areas. The contribution of this paper is the analysis of NBS in its different aspects throughout the implementation, identifying the lessons learned and barriers behind them. The results are describing each of the aspects analyzed in the selected references, to provide an overview of what is considered the problem-solving feature of NBS. Furthermore, complementary information of the cases (location, challenges, ES, types, scales) is used to report the specificities of the implementation experiences. There are still many opportunities and knowledge gaps to facilitate NBS operationalization, such as the different narratives around NBS and the local search for collaborations as processes that not only reveal the technical effectiveness of the challenges addressed but also the advances to the solution as a fixed vision or as a cross-boundary scheme that requires cross-sectoral dialogues.

Author Contributions: Conceptualization, N.A.R.-A., R.P.A., M.V. and E.R.; methodology, N.A.R.-A., R.P.A., M.V. and E.R.; validation, M.V. and E.R.; formal analysis, N.A.R.-A. and R.P.A.; investigation, N.A.R.-A., R.P.A. and E.R.; writing —original draft preparation, N.A.R.-A., R.P.A.; writing-review and editing, N.A.R.-A., E.R.; visualization, N.A.R.-A., R.P.A.; supervision, E.R.; funding acquisition, M.V. and E.R. All authors have read and agreed to the published version of the manuscript.

Funding: This research was partially funded by the Spanish Ministry of Science and Innovation, grant number PCI2019-103674 (MCIU/AEI/FEDER).

Acknowledgments: This paper is a product of the project Nature-Based Solutions for Water Management in the Peri-Urban: Linking Ecological, Social and Economic Dimensions (NATWIP), a project funded under the 2018 Joint Call of Water JPI. We are grateful to the NATWIP Consortium for their contributions to the refinement of this research, especially to Sarah Hale (NGI) \& Lina Suleiman (KTH). This version is integrating valuable insights from the fruitful discussions within the NATWIP meetings. We would like to thank Gerard Martinez Görbig for the support during the selection of references for its formal analysis.

Conflicts of Interest: The authors declare no conflict of interest. The funders had no role in the design of the study; in the collection, analyses or interpretation of data; in the writing of the manuscript; or in the decision to publish results.

\section{Appendix A}

Table A1. List of included references with case location and reference code.

\begin{tabular}{|c|c|c|c|c|c|}
\hline Code & Country & Location & Title & Authors & Year \\
\hline 1 & Denmark & Aarhus & $\begin{array}{l}\text { Making the ecosystem } \\
\text { services approach } \\
\text { operational: A case } \\
\text { study application to } \\
\text { the Aarhus River, } \\
\text { Denmark. }\end{array}$ & $\begin{array}{l}\text { Riegels, N.; } \\
\text { Lynggaard-Jensen, A.; } \\
\text { Krogsgaard Jensen, J.; } \\
\text { Gerner, N.V.; } \\
\text { Anzaldua, G.; Mark, O.; } \\
\text { Butts, M.; Birk, S. }\end{array}$ & 2020 \\
\hline 2 & $\begin{array}{l}\text { Denmark } \\
\text { Sweden }\end{array}$ & $\begin{array}{l}\text { Copenhagen } \\
\text { Kristianstad }\end{array}$ & $\begin{array}{l}\text { Fostering incidental } \\
\text { experiences of nature } \\
\text { through green } \\
\text { infrastructure } \\
\text { planning. }\end{array}$ & $\begin{array}{l}\text { Beery, T.H.; } \\
\text { Raymond, C.M.; Kyttä, } \\
\text { M.; Olafsson, A.S.; } \\
\text { Plieninger, T.; } \\
\text { Sandberg, M.; Stenseke, } \\
\text { M.; Tengö, M.; } \\
\text { Jönsson, K.I. }\end{array}$ & 2017 \\
\hline
\end{tabular}


Table A1. Cont.

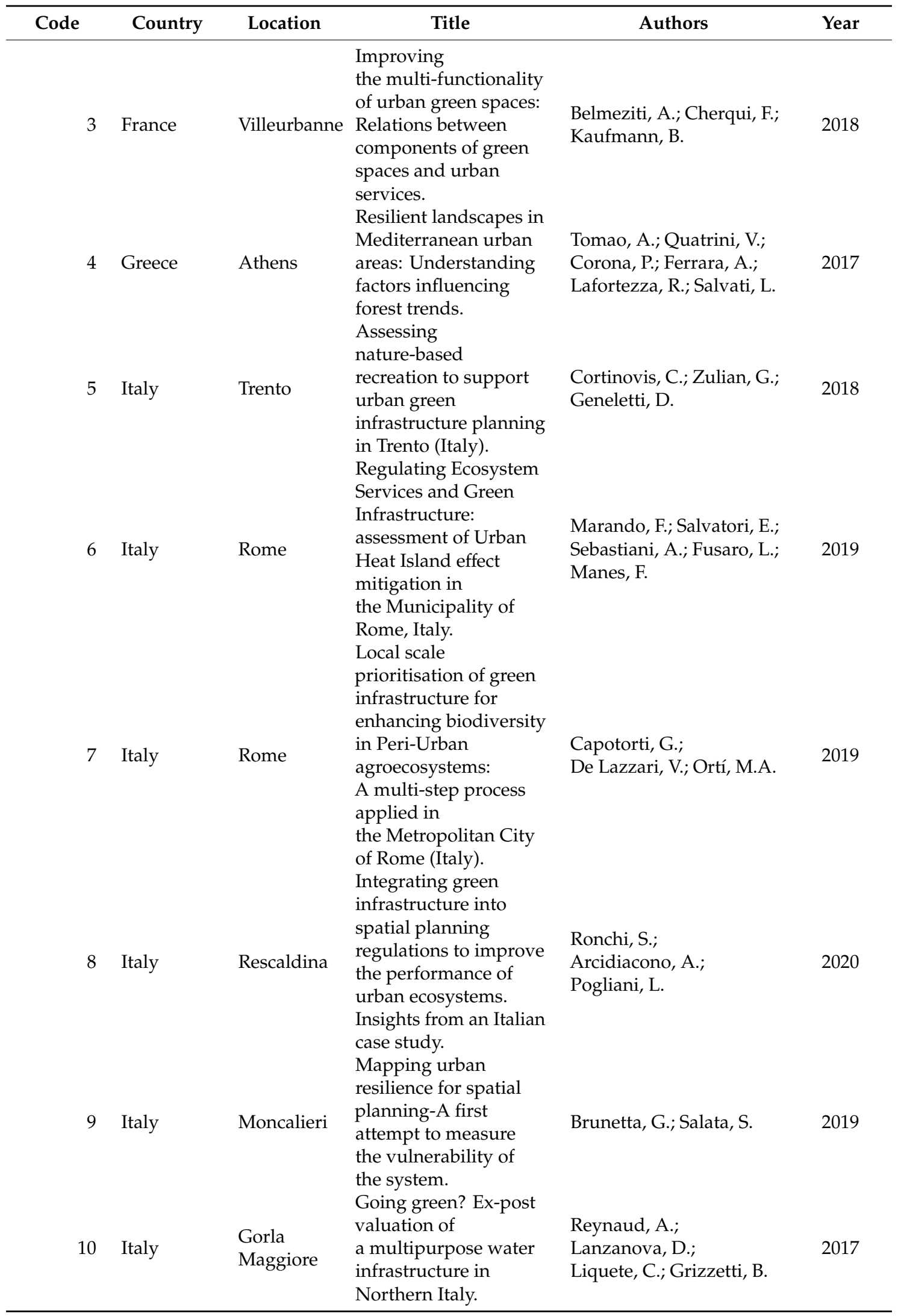


Table A1. Cont.

\begin{tabular}{|c|c|c|c|c|c|}
\hline Code & Country & Location & Title & Authors & Year \\
\hline 11 & Italy & $\begin{array}{l}\text { Gorla } \\
\text { Maggiore }\end{array}$ & $\begin{array}{l}\text { Integrated valuation of } \\
\text { a nature-based solution } \\
\text { for water pollution } \\
\text { control. Highlighting } \\
\text { hidden benefits. }\end{array}$ & $\begin{array}{l}\text { Liquete, C.; Udias, A.; } \\
\text { Conte, G.; Grizzetti, B.; } \\
\text { Masi, F. }\end{array}$ & 2016 \\
\hline 12 & Italy & Avola & $\begin{array}{l}\text { Planning for spatial } \\
\text { equity-A performance } \\
\text { based approach for } \\
\text { sustainable urban } \\
\text { drainage systems. }\end{array}$ & $\begin{array}{l}\text { La Rosa, D.; } \\
\text { Pappalardo, V. }\end{array}$ & 2020 \\
\hline 13 & $\begin{array}{l}\text { Poland } \\
\text { Slovakia }\end{array}$ & $\begin{array}{l}\text { Wroclaw } \\
\text { Bratislava }\end{array}$ & $\begin{array}{l}\text { The green } \\
\text { infrastructure in cities } \\
\text { as a tool for climate } \\
\text { change adaptation and } \\
\text { mitigation: Slovakian } \\
\text { and polish experiences. }\end{array}$ & $\begin{array}{l}\text { Belčáková, I.; } \\
\text { Świader, M.; } \\
\text { Bartyna-Zielińska, M. }\end{array}$ & 2019 \\
\hline 14 & Slovenia & Ljubljana & $\begin{array}{l}\text { Engaging stakeholders } \\
\text { in the assessment of } \\
\text { NBS effectiveness in } \\
\text { flood risk reduction: } \\
\text { A participatory System } \\
\text { Dynamics Model for } \\
\text { benefits and } \\
\text { co-benefits evaluation. }\end{array}$ & $\begin{array}{l}\text { Pagano, A.; } \\
\text { Pluchinotta, I.; Pengal, P.; } \\
\text { Cokan, B.; Giordano, R. }\end{array}$ & 2019 \\
\hline 15 & Spain & Barcelona & $\begin{array}{l}\text { Creating urban green } \\
\text { infrastructure where it } \\
\text { is needed-A spatial } \\
\text { ecosystem } \\
\text { service-based decision } \\
\text { analysis of green roofs } \\
\text { in Barcelona. }\end{array}$ & $\begin{array}{l}\text { Langemeyer, J.; } \\
\text { Wedgwood, D.; } \\
\text { McPhearson, T.; Baró, F.; } \\
\text { Madsen, A.L.; } \\
\text { Barton, D.N. }\end{array}$ & 2020 \\
\hline 16 & $\begin{array}{l}\text { United } \\
\text { Kingdom }\end{array}$ & London & $\begin{array}{l}\text { Accounting for } \\
\text { groundwater in future } \\
\text { city visions. }\end{array}$ & $\begin{array}{l}\text { Bricker, S.H.; Banks, V.J.; } \\
\text { Galik, G.; Tapete, D.; } \\
\text { Jones, R. }\end{array}$ & 2017 \\
\hline 17 & $\begin{array}{l}\text { United } \\
\text { Kingdom }\end{array}$ & Liverpool & $\begin{array}{l}\text { Re-defining } \\
\text { the characteristics of } \\
\text { environmental } \\
\text { volunteering: Creating } \\
\text { a typology of } \\
\text { community-scale green } \\
\text { infrastructure. }\end{array}$ & $\begin{array}{l}\text { Jerome, G.; Mell, I.; } \\
\text { Shaw, D. }\end{array}$ & 2017 \\
\hline 18 & $\begin{array}{l}\text { Germany } \\
\text { Germany } \\
\text { Netherlands } \\
\text { Norway } \\
\text { Cuba }\end{array}$ & $\begin{array}{l}\text { Andernach } \\
\text { Heidelberg } \\
\text { Rotterdam } \\
\text { Oslo } \\
\text { Havana }\end{array}$ & $\begin{array}{l}\text { Edible city } \\
\text { solutions-one step } \\
\text { further to foster social } \\
\text { resilience through } \\
\text { enhanced } \\
\text { socio-cultural } \\
\text { ecosystem services } \\
\text { in cities. }\end{array}$ & $\begin{array}{l}\text { Säumel, I.; Reddy, S.E.; } \\
\text { Wachtel, T. }\end{array}$ & 2019 \\
\hline 19 & $\begin{array}{l}\text { Spain } \\
\text { China }\end{array}$ & $\begin{array}{l}\text { Barcelona } \\
\text { Shanghai }\end{array}$ & $\begin{array}{l}\text { Nature-based solutions } \\
\text { for urban landscapes } \\
\text { under } \\
\text { post-industrialization } \\
\text { and globalization: } \\
\text { Barcelona versus } \\
\text { Shanghai. }\end{array}$ & $\begin{array}{l}\text { Fan, P.; Ouyang, Z.; } \\
\text { Basnou, C.; Pino, J.; } \\
\text { Park, H.; Chen, J. }\end{array}$ & 2017 \\
\hline
\end{tabular}


Table A1. Cont.

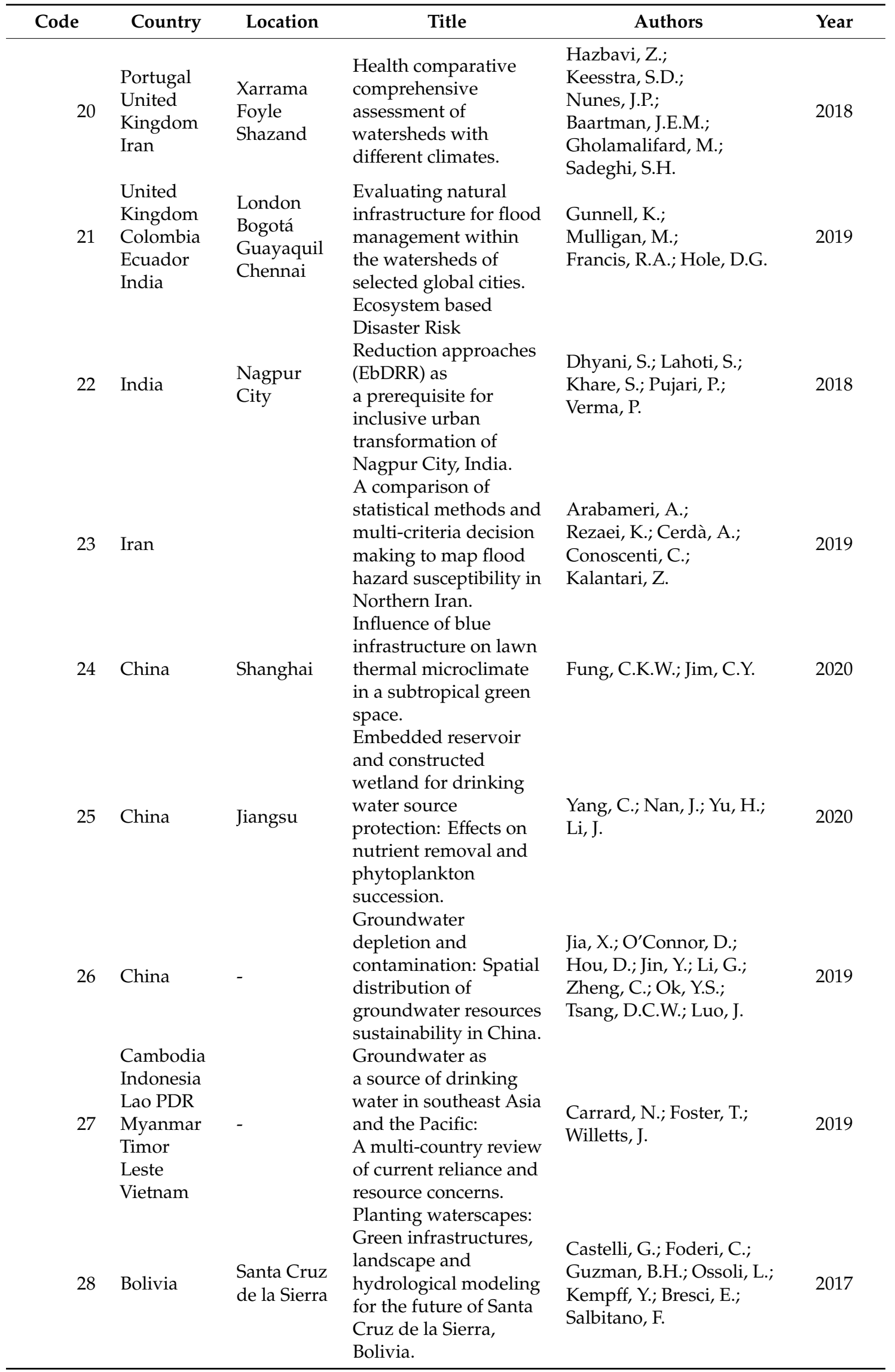


Table A1. Cont.

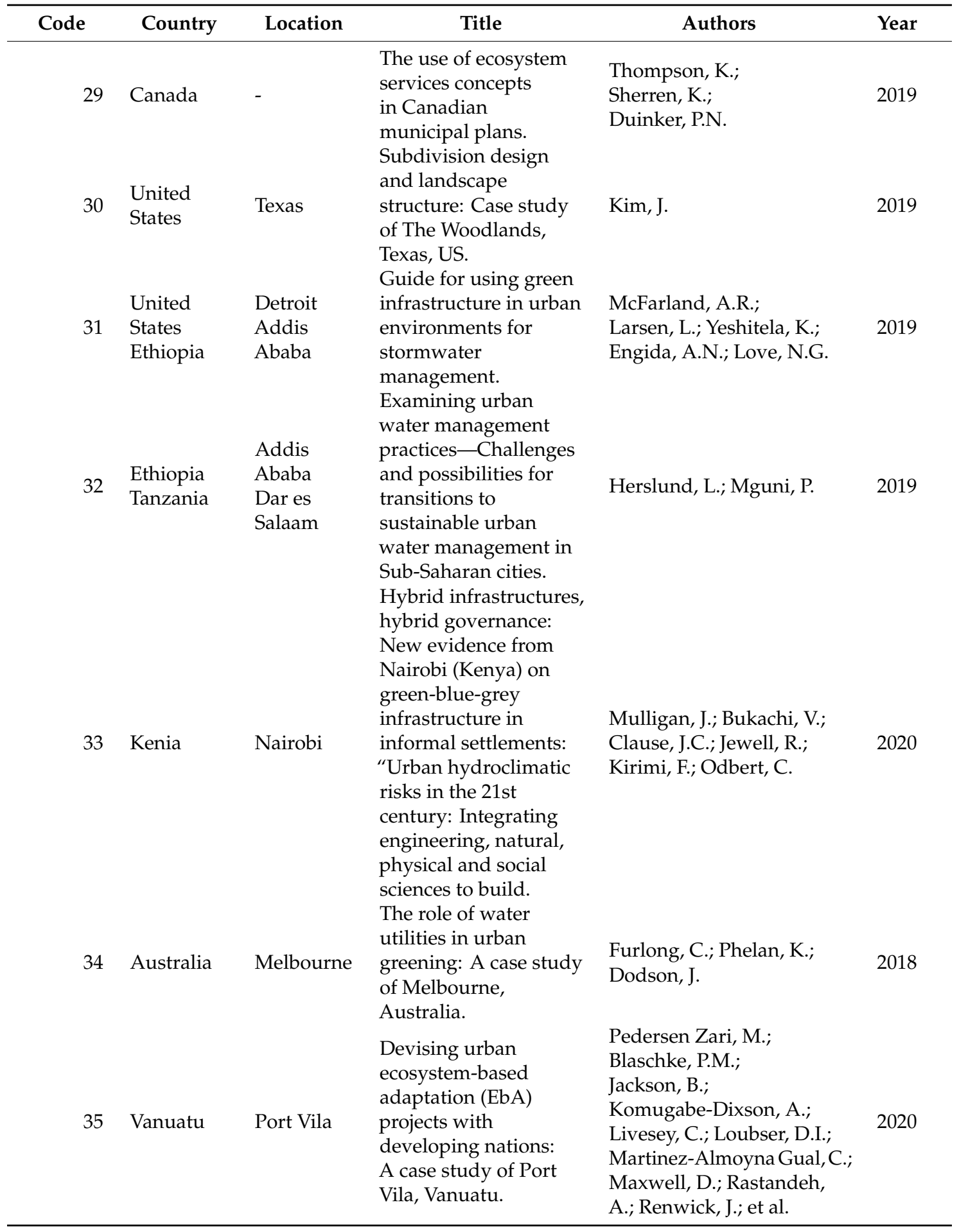


Table A2. List of cases with challenges and descriptions.

\begin{tabular}{|c|c|c|}
\hline Code & Challenges & Description \\
\hline 1 & $\begin{array}{l}\text { Effective-incorporation of } \\
\text { socio-cultural services }\end{array}$ & $\begin{array}{l}\text { River restoration } \\
\text { (to improve recreation and aesthetic aspects) }\end{array}$ \\
\hline 2 & $\begin{array}{l}\text { Effective-incorporation of } \\
\text { socio-cultural services }\end{array}$ & Incidental experience of nature \\
\hline 3 & $\begin{array}{l}\text { Stormwater management } \\
\text { Flood risks }\end{array}$ & Stormwater management \\
\hline 4 & $\begin{array}{l}\text { Freshwater withdrawals } \\
\text { Climate regulation }\end{array}$ & Regulating impacts on water through forests \\
\hline 5 & $\begin{array}{l}\text { Effective-incorporation of } \\
\text { socio-cultural services }\end{array}$ & Nature-based recreational systems \\
\hline 6 & Climate regulation & $\begin{array}{l}\text { (Not specific for water NBS) } \\
\text { Climate regulation }\end{array}$ \\
\hline 7 & $\begin{array}{l}\text { Urban water systems management } \\
\text { Freshwater withdrawals }\end{array}$ & $\begin{array}{l}\text { Preservation and improvement of ES and } \\
\text { landscape (water included) }\end{array}$ \\
\hline 8 & $\begin{array}{l}\text { Flood risks } \\
\text { Climate regulation }\end{array}$ & Flooding, urban heat island effect \\
\hline 9 & Freshwater withdrawals & Identification of vulnerability \\
\hline 10 & $\begin{array}{l}\text { Water pollution purification/filtration } \\
\text { Flood risks }\end{array}$ & Flood risk and water pollution \\
\hline 11 & Water pollution purification/filtration & Water pollution control \\
\hline 12 & $\begin{array}{l}\text { Climate change mitigation and/or } \\
\text { adaptation } \\
\text { Flood risks }\end{array}$ & $\begin{array}{l}\text { Flood risk due to climate change and } \\
\text { urbanization processes }\end{array}$ \\
\hline 13 & $\begin{array}{l}\text { Climate change mitigation and/or } \\
\text { adaptation } \\
\text { Climate regulation }\end{array}$ & Blue-green infrastructure \\
\hline 14 & $\begin{array}{l}\text { Flood risks } \\
\text { Effective-incorporation of } \\
\text { socio-cultural services }\end{array}$ & $\begin{array}{l}\text { Capability of NBS to produce co-benefits } \\
\text { (nature conservation, community well-being, } \\
\text { etc.) besides supporting risk reduction } \\
\text { (flood risk reduction) }\end{array}$ \\
\hline 15 & Stormwater management & Stormwater runoff control \\
\hline 16 & Water pollution purification/filtration & Groundwater Management \\
\hline 17 & $\begin{array}{l}\text { Effective-incorporation of } \\
\text { socio-cultural services }\end{array}$ & $\begin{array}{l}\text { Not related to water (but interesting for } \\
\text { community-scale engagement) }\end{array}$ \\
\hline 18 & $\begin{array}{l}\text { Climate change mitigation and/or } \\
\text { adaptation } \\
\text { Socio-cultural services } \\
\text { Climate regulation }\end{array}$ & Edible Cities \\
\hline 19 & (not specific for water NBS) & $\begin{array}{l}\text { Urban environmental challenges that arise as } \\
\text { a city rapidly urbanizes }\end{array}$ \\
\hline 20 & $\begin{array}{l}\text { Urban water systems management } \\
\text { Freshwater withdrawals }\end{array}$ & Watershed health assessment. \\
\hline 21 & Flood risks & Flood risk \\
\hline & Flood risks & Ecosystem-based Disaster Risk Reduction \\
\hline 22 & $\begin{array}{l}\text { Drought/Water scarcity } \\
\text { Climate regulation }\end{array}$ & $\begin{array}{l}\text { (EbDRR): water shortage, floods and } \\
\text { increasing temperature }\end{array}$ \\
\hline 23 & Flood risks & Flood hazard \\
\hline 24 & Climate regulation & Thermal microclimate regulation \\
\hline 25 & Freshwater supply & Preservation of drinking water \\
\hline 26 & Urban water systems management & Water Management \\
\hline 27 & Freshwater supply & Drinking water source \\
\hline 28 & $\begin{array}{l}\text { Drought/Water scarcity } \\
\text { Freshwater supply }\end{array}$ & decline in water supply for the city \\
\hline 29 & Freshwater withdrawals & Application of Ecosystem Services \\
\hline 30 & $\begin{array}{l}\text { Flood risks } \\
\text { Freshwater supply }\end{array}$ & Flood risk, water supply \\
\hline 31 & Stormwater management & Stormwater management \\
\hline
\end{tabular}


Table A2. Cont.

\begin{tabular}{|c|c|c|}
\hline Code & Challenges & Description \\
\hline 32 & $\begin{array}{l}\text { Urban water systems management } \\
\text { Freshwater supply }\end{array}$ & Water management and supply \\
\hline 33 & $\begin{array}{l}\text { Stormwater management } \\
\text { Urban water systems management }\end{array}$ & $\begin{array}{l}\text { stormwater management and } \\
\text { wastewater drainage }\end{array}$ \\
\hline 34 & $\begin{array}{l}\text { Urban water systems management } \\
\text { Freshwater withdrawals }\end{array}$ & Water utilities to ensure water security \\
\hline 35 & $\begin{array}{l}\text { Urban water systems management } \\
\text { Freshwater withdrawals }\end{array}$ & $\begin{array}{l}\text { Water security; Coastal ecosystems } \\
\text { regeneration; Integrated urban water systems } \\
\text { (stormwater, greywater, blackwater, } \\
\text { drinking water) }\end{array}$ \\
\hline
\end{tabular}

Table A3. Structure of ES and description (TEEB) and main aspects identified.

\begin{tabular}{|c|c|c|c|c|}
\hline ES & Description & Aspects Identified & & Codes \\
\hline \multirow{12}{*}{$\begin{array}{l}\text { Provisioning } \\
\text { Services }\end{array}$} & \multirow{3}{*}{ Food } & \multirow{3}{*}{ Food production } & Food supply & 4 \\
\hline & & & Food production & 15 \\
\hline & & & Improve (edible cities) & 18 \\
\hline & Raw materials & $\begin{array}{l}\text { Raw materials } \\
\text { production }\end{array}$ & Wood extraction & 11 \\
\hline & \multirow{7}{*}{ Freshwater } & \multirow{7}{*}{$\begin{array}{l}\text { Rain water } \\
\text { harvesting }\end{array}$} & Water yield & 8 \\
\hline & & & Control and assure water supply & 9 \\
\hline & & & Water supply & $16 ; 32$ \\
\hline & & & Water harvesting & 22 \\
\hline & & & Drinking water sources & 25 \\
\hline & & & Drinking water supplies & 27 \\
\hline & & & Freshwater supply & 28 \\
\hline & $\begin{array}{l}\text { Medicinal } \\
\text { Resources }\end{array}$ & Not identified & & \\
\hline \multirow{20}{*}{$\begin{array}{l}\text { Regulating } \\
\text { Services }\end{array}$} & \multirow{8}{*}{$\begin{array}{l}\text { Local Climate } \\
\text { Air Quality }\end{array}$} & \multirow{8}{*}{ Climate regulation } & Mitigate urban heat island effect & 3 \\
\hline & & & Climate regulation & 6 \\
\hline & & & (Cooling Capacity of Green & \\
\hline & & & $\begin{array}{l}\text { Infrastructure elements obtained } \\
\text { from land surface temperature) }\end{array}$ & \\
\hline & & & Microclimate adaptation & 8 \\
\hline & & & Thermal regulation & 15 \\
\hline & & & $\begin{array}{l}\text { Microclimate regulation } \\
\text { (reduced UHI) }\end{array}$ & 22 \\
\hline & & & Cooling capacity & 24 \\
\hline & \multirow{3}{*}{$\begin{array}{l}\text { Carbon } \\
\text { sequestration and } \\
\text { storage }\end{array}$} & \multirow{2}{*}{$\begin{array}{l}\text { Carbon } \\
\text { sequestration }\end{array}$} & Carbon sequestration & 8 \\
\hline & & & $\begin{array}{l}\text { Carbon sequestration } \\
\text { (carbon sink) }\end{array}$ & 22 \\
\hline & & \multirow{6}{*}{ Flood protection } & Water level fluctuation & 2 \\
\hline & \multirow{9}{*}{$\begin{array}{l}\text { Moderation of } \\
\text { extreme events }\end{array}$} & & $\begin{array}{l}\text { Reduce water volume, retain } \\
\text { peak flow, recharge groundwater }\end{array}$ & 3 \\
\hline & & & Flood protection & $7 ; 11$ \\
\hline & & & Flood prevention & 10 \\
\hline & & & Flood regulation and control & 21 \\
\hline & & & Flood control & 23 \\
\hline & & \multirow{4}{*}{$\begin{array}{l}\text { Stormwater runoff } \\
\text { control }\end{array}$} & $\begin{array}{l}\text { Water drainage } \\
\text { (runoff mitigation, stormwater } \\
\text { management) }\end{array}$ & 8 \\
\hline & & & Stormwater runoff control & 15 \\
\hline & & & $\begin{array}{l}\text { Decelerate rainwater runoff and } \\
\text { minimizing flood peaks }\end{array}$ & 22 \\
\hline & & & Runoff mitigation & 31 \\
\hline
\end{tabular}


Table A3. Cont.

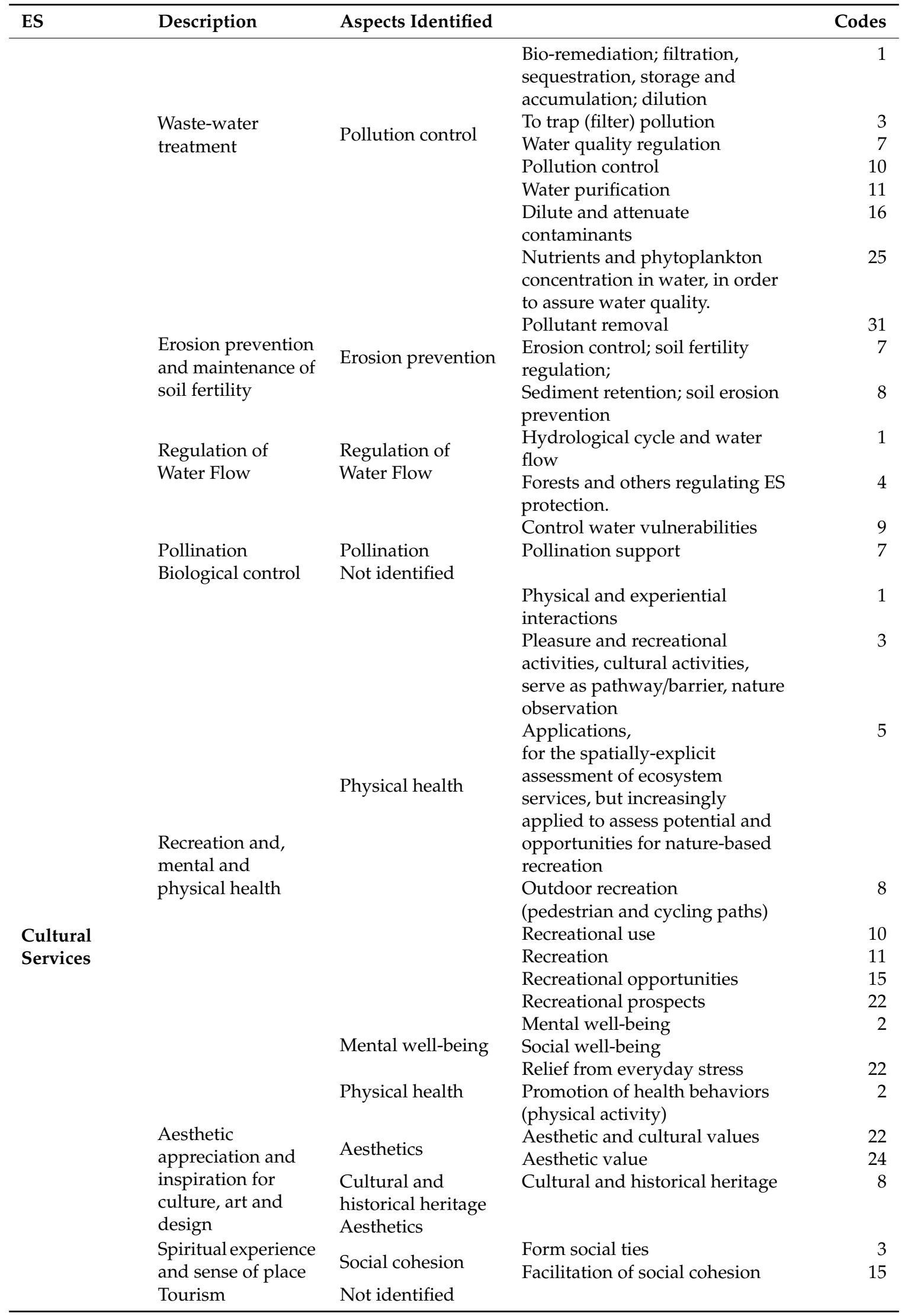


Table A3. Cont.

\begin{tabular}{|c|c|c|c|c|}
\hline ES & Description & Aspects Identified & & Codes \\
\hline \multirow{6}{*}{$\begin{array}{l}\text { Supporting } \\
\text { Services }\end{array}$} & \multirow{5}{*}{ Habitat for species } & \multirow{5}{*}{$\begin{array}{l}\text { Natural } \\
\text { habitat/shelter }\end{array}$} & $\begin{array}{l}\text { Nursery populations and } \\
\text { habitats }\end{array}$ & 1 \\
\hline & & & $\begin{array}{l}\text { Habitat/shelter for fauna/flora, } \\
\text { good resources for fauna }\end{array}$ & 3 \\
\hline & & & $\begin{array}{l}\text { Conservation of crops and } \\
\text { farmland. }\end{array}$ & 7 \\
\hline & & & Maintenance of natural habitats & 11 \\
\hline & & & Habitats for pollinators & 15 \\
\hline & $\begin{array}{l}\text { Maintenance of } \\
\text { genetic diversity }\end{array}$ & Not identified & & \\
\hline
\end{tabular}

Table A4. List of cases with Ecosystem services.

\begin{tabular}{|c|c|c|c|c|}
\hline Code & $\begin{array}{l}\text { Provisioning } \\
\text { Services }\end{array}$ & Regulating Services & Cultural Services & $\begin{array}{l}\text { Supporting } \\
\text { Services }\end{array}$ \\
\hline 1 & \multirow{9}{*}{ Food } & $\begin{array}{l}\text { Waste-water treatment } \\
\text { Regulation of Water Flow }\end{array}$ & $\begin{array}{l}\text { Recreation and, mental } \\
\text { and physical health }\end{array}$ & \multirow[t]{3}{*}{ Habitat for species } \\
\hline 2 & & Moderation of extreme events & $\begin{array}{l}\text { Recreation and, mental } \\
\text { and physical health }\end{array}$ & \\
\hline & & Local Climate Air Quality & $\begin{array}{l}\text { Recreation and, mental } \\
\text { and physical health }\end{array}$ & \\
\hline 3 & & Moderation of extreme events & $\begin{array}{l}\text { Spiritual experience and } \\
\text { sense of place }\end{array}$ & \multirow[t]{4}{*}{ Habitat for species } \\
\hline 4 & & $\begin{array}{l}\text { Waste-water treatment } \\
\text { Regulation of Water Flow }\end{array}$ & & \\
\hline 5 & & & $\begin{array}{l}\text { Recreation and, mental } \\
\text { and physical health }\end{array}$ & \\
\hline 6 & & $\begin{array}{l}\text { Local Climate Air Quality } \\
\text { Moderation of extreme events } \\
\text { Waste-water treatment }\end{array}$ & & \\
\hline 7 & & $\begin{array}{l}\text { Erosion prevention and } \\
\text { maintenance of soil fertility } \\
\text { Pollination }\end{array}$ & & \multirow[t]{6}{*}{ Habitat for species } \\
\hline & & $\begin{array}{l}\text { Local Climate Air Quality } \\
\text { Carbon sequestration and } \\
\text { storage }\end{array}$ & $\begin{array}{l}\text { Recreation and, mental } \\
\text { and physical health }\end{array}$ & \\
\hline 8 & Freshwater & Moderation of extreme events & $\begin{array}{l}\text { Aesthetic appreciation } \\
\text { and inspiration for } \\
\text { culture, art and design }\end{array}$ & \\
\hline & & $\begin{array}{l}\text { Erosion prevention and } \\
\text { maintenance of soil fertility }\end{array}$ & & \\
\hline 9 & Freshwater & Regulation of Water Flow & \multirow{6}{*}{$\begin{array}{l}\text { Recreation and, mental } \\
\text { and physical health } \\
\text { Recreation and, mental } \\
\text { and physical health } \\
\text { Recreation and, mental } \\
\text { and physical health } \\
\text { Spiritual experience and } \\
\text { sense of place }\end{array}$} & \\
\hline 10 & & $\begin{array}{l}\text { Moderation of extreme events } \\
\text { Waste-water treatment }\end{array}$ & & \\
\hline 11 & $\begin{array}{l}\text { Raw } \\
\text { materials }\end{array}$ & $\begin{array}{l}\text { Moderation of extreme events } \\
\text { Waste-water treatment }\end{array}$ & & Habitat for species \\
\hline 15 & Food & $\begin{array}{l}\text { Local Climate Air Quality } \\
\text { Moderation of extreme events }\end{array}$ & & \multirow[t]{3}{*}{ Habitat for species } \\
\hline $\begin{array}{l}16 \\
18\end{array}$ & $\begin{array}{l}\text { Freshwater } \\
\text { Food }\end{array}$ & Waste-water treatment & & \\
\hline 21 & & Moderation of extreme events & & \\
\hline
\end{tabular}


Table A4. Cont.

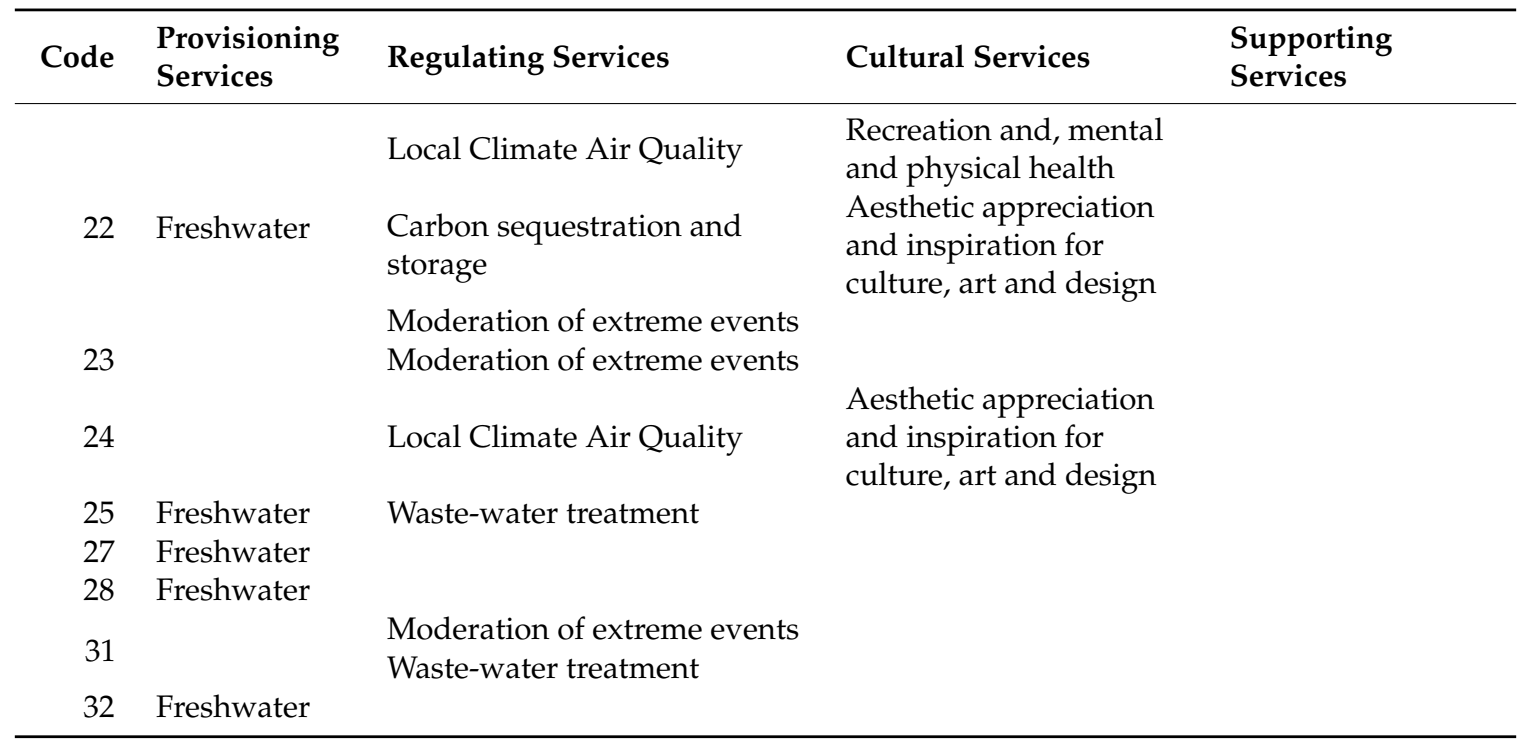

Table A5. Summary of NBS types, challenges and Ecosystem Services.

\begin{tabular}{|c|c|c|c|}
\hline Code & NBS Types & Challenges & Ecosystem Services \\
\hline 1 & Other & $\begin{array}{l}\text { Effective-incorporation } \\
\text { of socio-cultural services }\end{array}$ & $\begin{array}{l}\text { Waste-water treatment } \\
\text { Regulation of Water Flow Recreation and, } \\
\text { mental and physical health } \\
\text { Habitat for species }\end{array}$ \\
\hline 2 & $\begin{array}{l}\text { Wetland } \\
\text { Other }\end{array}$ & $\begin{array}{l}\text { Effective-incorporation } \\
\text { of socio-cultural services }\end{array}$ & $\begin{array}{l}\text { Moderation of extreme events } \\
\text { Recreation and, mental and physical health } \\
\text { Local Climate Air Quality }\end{array}$ \\
\hline 3 & $\begin{array}{l}\text { Green roof/wall } \\
\text { Permeable } \\
\text { pavement } \\
\text { Other }\end{array}$ & Stormwater management & $\begin{array}{l}\text { Moderation of extreme events } \\
\text { Waste-water treatment Recreation and, } \\
\text { mental and physical health } \\
\text { Spiritual experience and sense of place } \\
\text { Habitat for species }\end{array}$ \\
\hline 4 & $\begin{array}{l}\text { River park } \\
\text { Wetland } \\
\text { Other } \\
\text { River park }\end{array}$ & $\begin{array}{l}\text { Flood risks } \\
\text { Freshwater withdrawals } \\
\text { Climate regulation }\end{array}$ & $\begin{array}{l}\text { Food } \\
\text { Regulation of Water Flow }\end{array}$ \\
\hline 5 & $\begin{array}{l}\text { Agroforestry } \\
\text { Wetland } \\
\text { Park }\end{array}$ & $\begin{array}{l}\text { Effective-incorporation } \\
\text { of Socio-cultural services }\end{array}$ & Recreation and, mental and physical health \\
\hline 6 & Other & Climate regulation & $\begin{array}{l}\text { Local Climate Air Quality } \\
\text { Moderation of extreme events }\end{array}$ \\
\hline 7 & $\begin{array}{l}\text { SUDS } \\
\text { Agroforestry } \\
\text { Park } \\
\text { Other }\end{array}$ & $\begin{array}{l}\text { Urban water systems } \\
\text { management } \\
\text { Freshwater withdrawals }\end{array}$ & $\begin{array}{l}\text { Waste-water treatment } \\
\text { Erosion prevention and maintenance of } \\
\text { soil fertility } \\
\text { Pollination } \\
\text { Habitat for species }\end{array}$ \\
\hline 8 & $\begin{array}{l}\text { Green roof/wall } \\
\text { Park } \\
\text { Rain } \\
\text { Garden } \\
\text { Phytorid treatment } \\
\text { Permeable } \\
\text { pavement } \\
\text { Other }\end{array}$ & $\begin{array}{l}\text { Flood risks } \\
\text { Climate regulation }\end{array}$ & $\begin{array}{l}\text { Freshwater } \\
\text { Local Climate Air Quality } \\
\text { Carbon sequestration and storage } \\
\text { Moderation of extreme events } \\
\text { Erosion prevention and maintenance of } \\
\text { soil fertility } \\
\text { Recreation and, mental and physical health } \\
\text { Aesthetic appreciation and inspiration for } \\
\text { culture, art and design }\end{array}$ \\
\hline
\end{tabular}


Table A5. Cont.

\begin{tabular}{|c|c|c|c|}
\hline Code & NBS Types & Challenges & Ecosystem Services \\
\hline 9 & $\begin{array}{l}\text { SUDS } \\
\text { Green roof/wall } \\
\text { River park } \\
\text { Agroforestry } \\
\text { Park } \\
\text { Other }\end{array}$ & Freshwater withdrawals & $\begin{array}{l}\text { Freshwater } \\
\text { Regulation of Water Flow }\end{array}$ \\
\hline 10 & $\begin{array}{l}\text { River park } \\
\text { Wetland }\end{array}$ & $\begin{array}{l}\text { Water pollution } \\
\text { purification/filtration } \\
\text { Flood risks }\end{array}$ & $\begin{array}{l}\text { Moderation of extreme events } \\
\text { Waste-water treatment Recreation and, } \\
\text { mental and physical health }\end{array}$ \\
\hline 11 & $\begin{array}{l}\text { River park } \\
\text { Wetland }\end{array}$ & $\begin{array}{l}\text { Water pollution } \\
\text { purification/filtration }\end{array}$ & $\begin{array}{l}\text { Raw materials production } \\
\text { Moderation of extreme events } \\
\text { Waste-water treatment Recreation and, } \\
\text { mental and physical health } \\
\text { Habitat for species }\end{array}$ \\
\hline 12 & $\begin{array}{l}\text { SUDS } \\
\text { Green roof/wall } \\
\text { Wetland } \\
\text { Bioswale } \\
\text { Permeable } \\
\text { pavement } \\
\text { SUDS } \\
\text { Green roof/wall } \\
\text { River park } \\
\text { Agroforestry } \\
\text { Wetland } \\
\text { Park }\end{array}$ & $\begin{array}{l}\text { Climate change } \\
\text { mitigation and/or } \\
\text { adaptation } \\
\text { Climate regulation }\end{array}$ & ${ }^{2}$ \\
\hline 14 & Wetland & $\begin{array}{l}\text { Flood risks } \\
\text { Effective-incorporation } \\
\text { of socio-cultural services }\end{array}$ & - \\
\hline 15 & Green roof/wall & Stormwater management & $\begin{array}{l}\text { Food } \\
\text { Local Climate Air Quality } \\
\text { Moderation of extreme events } \\
\text { Recreation and, mental and physical health } \\
\text { Spiritual experience and } \\
\text { sense of place } \\
\text { Habitat for species }\end{array}$ \\
\hline 16 & $\begin{array}{l}\text { SUDS } \\
\text { Green roof/wall } \\
\text { River park } \\
\text { Agroforestry } \\
\text { Wetland } \\
\text { Park }\end{array}$ & $\begin{array}{l}\text { Water pollution } \\
\text { purification/filtration }\end{array}$ & $\begin{array}{l}\text { Freshwater } \\
\text { Waste-water treatment }\end{array}$ \\
\hline 17 & Other & $\begin{array}{l}\text { Effective-incorporation } \\
\text { of socio-cultural services }\end{array}$ & - \\
\hline 18 & $\begin{array}{l}\text { SUDS } \\
\text { Green roof/wall } \\
\text { River park } \\
\text { Agroforestry } \\
\text { Wetland } \\
\text { Park }\end{array}$ & $\begin{array}{l}\text { Climate change } \\
\text { mitigation and/or } \\
\text { adaptation } \\
\text { Effective-incorporation } \\
\text { of socio-cultural services } \\
\text { Climate regulation }\end{array}$ & Food \\
\hline 19 & Other & $\begin{array}{l}\text { (not specific for water } \\
\text { NBS) }\end{array}$ & - \\
\hline 20 & Other & $\begin{array}{l}\text { Urban water systems } \\
\text { management } \\
\text { Freshwater withdrawals }\end{array}$ & - \\
\hline 21 & $\begin{array}{l}\text { Wetland } \\
\text { Other }\end{array}$ & Flood risks & Moderation of extreme events \\
\hline
\end{tabular}


Table A5. Cont.

\begin{tabular}{|c|c|c|c|}
\hline Code & NBS Types & Challenges & Ecosystem Services \\
\hline \multirow{5}{*}{22} & \multirow{5}{*}{$\begin{array}{l}\text { Phytorid treatment } \\
\text { Other }\end{array}$} & & Freshwater \\
\hline & & & Local Climate Air Quality \\
\hline & & Flood risks & Carbon sequestration and storage \\
\hline & & Drought/Water scarcity & Moderation of extreme events \\
\hline & & Climate regulation & $\begin{array}{l}\text { Recreation and, mental and physical health } \\
\text { Aesthetic appreciation and inspiration for } \\
\text { culture, art and design }\end{array}$ \\
\hline 23 & Other & Flood risks & Moderation of extreme events \\
\hline \multirow[t]{2}{*}{24} & Other & Climate regulation & $\begin{array}{l}\text { Local Climate Air Quality Aesthetic } \\
\text { appreciation and inspiration for culture, } \\
\text { art and design }\end{array}$ \\
\hline & Wetland & \multirow[b]{2}{*}{ Freshwater supply } & Freshwater \\
\hline 25 & $\begin{array}{l}\text { Phytorid treatment } \\
\text { Other }\end{array}$ & & \multirow[t]{2}{*}{ Waste-water treatment } \\
\hline 26 & Other & $\begin{array}{l}\text { Urban water systems } \\
\text { management }\end{array}$ & \\
\hline 27 & Other & Freshwater supply & Freshwater \\
\hline \multirow[t]{2}{*}{28} & $\begin{array}{l}\text { SUDS } \\
\text { Green roof/wall } \\
\text { Agroforestry }\end{array}$ & $\begin{array}{l}\text { Drought/Water scarcity } \\
\text { Freshwater supply }\end{array}$ & \multirow[t]{2}{*}{ Freshwater } \\
\hline & $\begin{array}{l}\text { SUDS } \\
\text { Green roof/wall }\end{array}$ & \multirow[b]{2}{*}{ Freshwater withdrawals } & \\
\hline 29 & $\begin{array}{l}\text { River park } \\
\text { Agroforestry } \\
\text { Wetland } \\
\text { Park }\end{array}$ & & - \\
\hline \multirow[t]{3}{*}{30} & Agroforestry & Flood risks & \multirow[t]{2}{*}{-} \\
\hline & $\begin{array}{l}\text { Other } \\
\text { SUDS }\end{array}$ & Freshwater supply & \\
\hline & $\begin{array}{l}\text { Green roof/wall } \\
\text { Wetland }\end{array}$ & & \\
\hline \multirow{2}{*}{31} & Rain garden & \multirow{2}{*}{ Stormwater management } & Moderation of extreme events \\
\hline & $\begin{array}{l}\text { Bioswale } \\
\text { Permeable } \\
\text { pavement } \\
\text { Other }\end{array}$ & & Waste-water treatment \\
\hline 32 & $\begin{array}{l}\text { SUDS } \\
\text { Other }\end{array}$ & $\begin{array}{l}\text { Urban water systems } \\
\text { management } \\
\text { Freshwater supply }\end{array}$ & Freshwater \\
\hline 33 & $\begin{array}{l}\text { SUDS } \\
\text { Wetland } \\
\text { Rain garden } \\
\text { Other }\end{array}$ & $\begin{array}{l}\text { Stormwater management } \\
\text { Urban water systems } \\
\text { management }\end{array}$ & - \\
\hline 34 & Other & $\begin{array}{l}\text { Urban water systems } \\
\text { management } \\
\text { Freshwater withdrawals }\end{array}$ & - \\
\hline 35 & Other & $\begin{array}{l}\text { Urban water systems } \\
\text { management } \\
\text { Freshwater withdrawals }\end{array}$ & - \\
\hline
\end{tabular}


Table A6. Summary of NBS types and scales with descriptions.

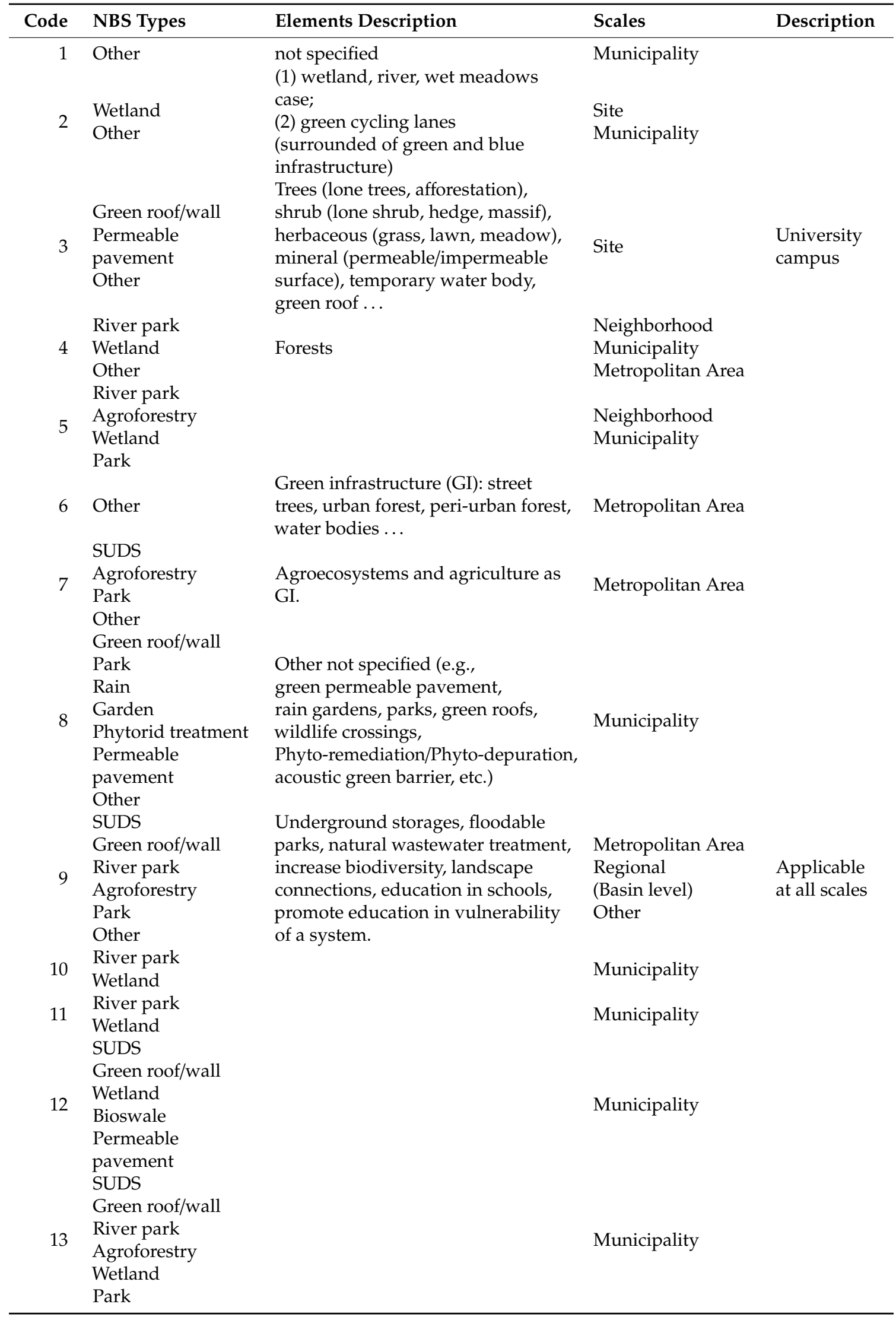


Table A6. Cont.

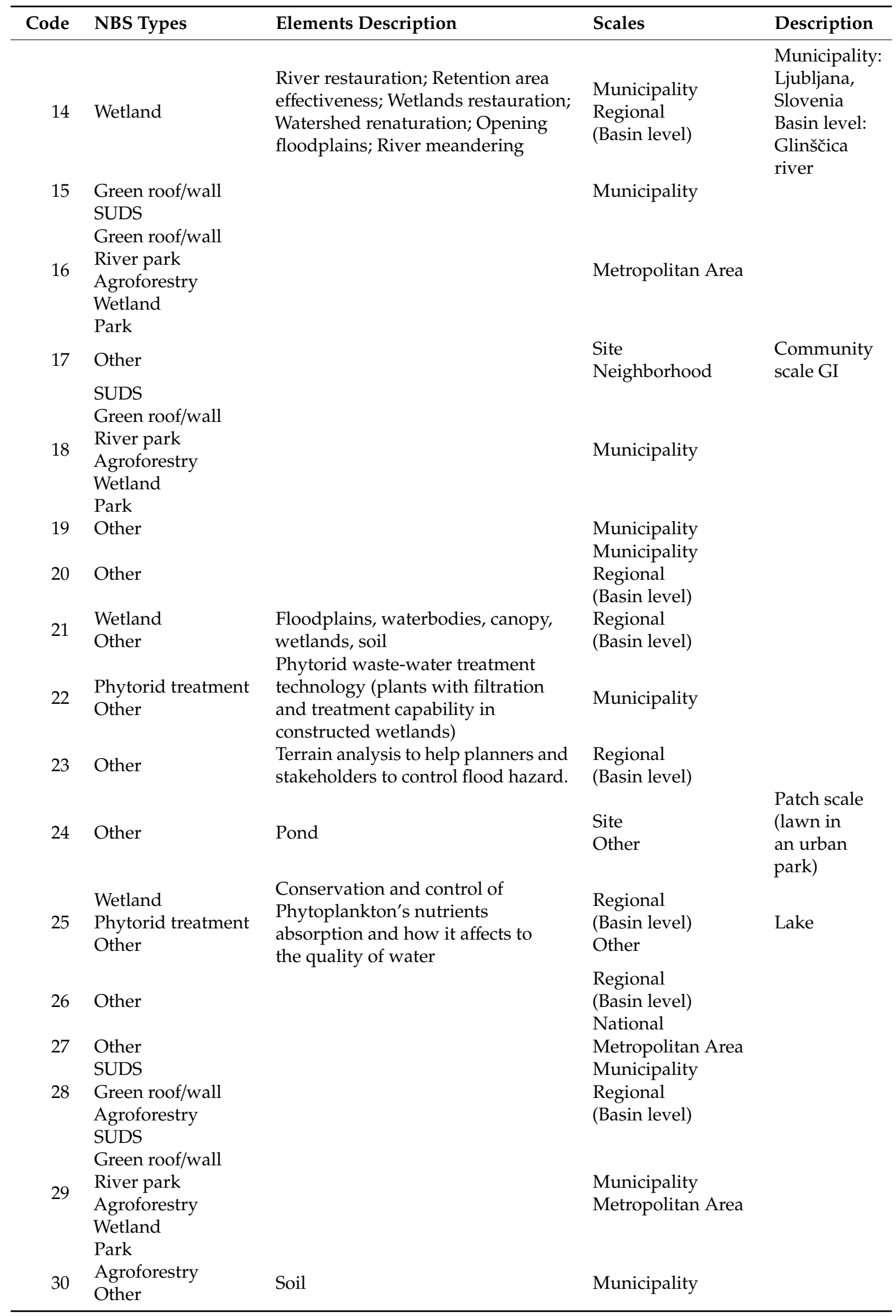


Table A6. Cont.

\begin{tabular}{|c|c|c|c|c|}
\hline Code & NBS Types & Elements Description & Scales & Description \\
\hline 31 & $\begin{array}{l}\text { SUDS } \\
\text { Green roof/wall } \\
\text { Wetland } \\
\text { Rain garden } \\
\text { Bioswale } \\
\text { Permeable } \\
\text { pavement } \\
\text { Other }\end{array}$ & $\begin{array}{l}\text { Retention basins; rainwater } \\
\text { harvesting; constructed wetlands; } \\
\text { detention basins; bioswales; } \\
\text { rain gardens; green roofs; permeable } \\
\text { pavements }\end{array}$ & $\begin{array}{l}\text { Site } \\
\text { Municipality } \\
\text { Regional } \\
\text { (Basin level) }\end{array}$ & \\
\hline 32 & $\begin{array}{l}\text { SUDS } \\
\text { Other }\end{array}$ & $\begin{array}{l}\text { Water harvesting, stormwater } \\
\text { drainage, building gabions, planting } \\
\text { next to the river }\end{array}$ & $\begin{array}{l}\text { Neighborhood } \\
\text { Municipality }\end{array}$ & \\
\hline 33 & $\begin{array}{l}\text { SUDS } \\
\text { Wetland } \\
\text { Rain garden } \\
\text { Other }\end{array}$ & bio-filtration & $\begin{array}{l}\text { Site } \\
\text { Neighborhood }\end{array}$ & $\begin{array}{l}\text { local } \\
\text { community } \\
\text { scale }\end{array}$ \\
\hline 34 & Other & $\begin{array}{l}\text { (1) Transformation of concrete } \\
\text { drainage channel into semi-natural } \\
\text { waterway; (2) Planting trees along } \\
\text { waterways, drainage corridors and } \\
\text { parks; } \\
\text { (3) Transformation of Sewer reserve } \\
\text { into linear park and bike track } \\
\text { Riparian corridor regeneration; } \\
\text { Restauration and protection of } \\
\text { coastal vegetation; Intensification of } \\
\text { peri-urban home garden; } \\
\text { Urban trees and vegetation }\end{array}$ & $\begin{array}{l}\text { Regional } \\
\text { (Basin level) }\end{array}$ & \\
\hline
\end{tabular}

Table A7. Summary of cases with location, spatial scale, instruments scales and actors involved.

\begin{tabular}{|c|c|c|c|c|c|}
\hline Code & Country & Location & Spatial & $\begin{array}{l}\text { Policy } \\
\text { Instruments }\end{array}$ & Actors \\
\hline 1 & Denmark & Aarhus & Municipality & Regional & $\begin{array}{l}\text { Public authorities } \\
\text { Academic and research bodies }\end{array}$ \\
\hline 2 & $\begin{array}{l}\text { Denmark } \\
\text { Sweden }\end{array}$ & $\begin{array}{l}\text { Copenhagen } \\
\text { Kristianstad }\end{array}$ & $\begin{array}{l}\text { Site } \\
\text { Municipality }\end{array}$ & $\begin{array}{l}\text { Global } \\
\text { Municipal }\end{array}$ & \\
\hline 3 & France & Villeurbanne & Site & & $\begin{array}{l}\text { Academic and research bodies } \\
\text { Water-related actors }\end{array}$ \\
\hline 4 & Greece & Athens & $\begin{array}{l}\text { Neighborhood } \\
\text { Municipality } \\
\text { Metropolitan Area }\end{array}$ & & Academic and research bodies \\
\hline 5 & Italy & Trento & $\begin{array}{l}\text { Neighborhood } \\
\text { Municipality }\end{array}$ & & $\begin{array}{l}\text { Water-related actors } \\
\text { Industry, business and private } \\
\text { sector }\end{array}$ \\
\hline 6 & Italy & Rome & Metropolitan Area & & $\begin{array}{l}\text { Academic and research bodies } \\
\text { Public authorities }\end{array}$ \\
\hline 7 & Italy & Rome & Metropolitan Area & Regional & $\begin{array}{l}\text { Civil society } \\
\text { Academic and research bodies }\end{array}$ \\
\hline 8 & Italy & Rescaldina & Municipality & $\begin{array}{l}\text { Sub-national } \\
\text { Municipal }\end{array}$ & $\begin{array}{l}\text { Public authorities } \\
\text { Academic and research bodies }\end{array}$ \\
\hline 9 & Italy & Moncalieri & $\begin{array}{l}\text { Metropolitan Area } \\
\text { Regional } \\
\text { (Basin level) } \\
\text { Other }\end{array}$ & National & $\begin{array}{l}\text { Public authorities } \\
\text { Academic and research bodies }\end{array}$ \\
\hline
\end{tabular}


Table A7. Cont.

\begin{tabular}{|c|c|c|c|c|c|}
\hline Code & Country & Location & Spatial & $\begin{array}{l}\text { Policy } \\
\text { Instruments }\end{array}$ & Actors \\
\hline 10 & Italy & $\begin{array}{l}\text { Gorla } \\
\text { Maggiore }\end{array}$ & Municipality & $\begin{array}{l}\text { Regional } \\
\text { Sub-national }\end{array}$ & $\begin{array}{l}\text { Public authorities } \\
\text { Civil society } \\
\text { Academic and research bodies } \\
\text { Water-related actors } \\
\text { Public authorities }\end{array}$ \\
\hline 11 & Italy & $\begin{array}{l}\text { Gorla } \\
\text { Maggiore }\end{array}$ & Municipality & $\begin{array}{l}\text { Regional } \\
\text { Sub-national }\end{array}$ & $\begin{array}{l}\text { Civil society } \\
\text { Academic and research bodies } \\
\text { Water-related actors }\end{array}$ \\
\hline 12 & Italy & Avola & Municipality & & Academic and research bodies \\
\hline 13 & $\begin{array}{l}\text { Poland } \\
\text { Slovakia }\end{array}$ & $\begin{array}{l}\text { Wroclaw } \\
\text { Bratislava }\end{array}$ & Municipality & $\begin{array}{l}\text { Global } \\
\text { Regional } \\
\text { National } \\
\text { Municipal }\end{array}$ & $\begin{array}{l}\text { Public authorities } \\
\text { Civil society } \\
\text { Academic and research bodies }\end{array}$ \\
\hline 14 & Slovenia & Ljubljana & $\begin{array}{l}\text { Municipality } \\
\text { Regional } \\
\text { (Basin level) }\end{array}$ & Regional & $\begin{array}{l}\text { Public authorities } \\
\text { Civil society }\end{array}$ \\
\hline 15 & Spain & Barcelona & Municipality & & $\begin{array}{l}\text { Public authorities } \\
\text { Civil society } \\
\text { Academic and research bodies } \\
\text { Industry, business and private } \\
\text { sector }\end{array}$ \\
\hline 16 & $\begin{array}{l}\text { United } \\
\text { Kingdom }\end{array}$ & London & Metropolitan Area & $\begin{array}{l}\text { Sub-national } \\
\text { National }\end{array}$ & $\begin{array}{l}\text { Public authorities } \\
\text { Civil society } \\
\text { Industry, business and private } \\
\text { sector }\end{array}$ \\
\hline 17 & $\begin{array}{l}\text { United } \\
\text { Kingdom }\end{array}$ & Liverpool & Site Neighborhood & Local & Civil society \\
\hline 18 & $\begin{array}{l}\text { Germany } \\
\text { Germany } \\
\text { Netherland } \\
\text { Norway } \\
\text { Cuba }\end{array}$ & $\begin{array}{l}\text { Andernach } \\
\text { Heidelberg } \\
\text { sRotterdam } \\
\text { Oslo } \\
\text { Havana }\end{array}$ & Municipality & Municipal & $\begin{array}{l}\text { Public authorities } \\
\text { Civil society } \\
\text { Academic and research bodies }\end{array}$ \\
\hline 19 & $\begin{array}{l}\text { Spain } \\
\text { China }\end{array}$ & $\begin{array}{l}\text { Barcelona } \\
\text { Shanghai }\end{array}$ & Municipality & Municipal & Public authorities \\
\hline 20 & $\begin{array}{l}\text { Portugal } \\
\text { United } \\
\text { Kingdom } \\
\text { Iran }\end{array}$ & $\begin{array}{l}\text { Xarrama } \\
\text { Foyle } \\
\text { Shazand }\end{array}$ & $\begin{array}{l}\text { Municipality } \\
\text { Regional } \\
\text { (Basin level) }\end{array}$ & Global & Academic and research bodies \\
\hline 21 & $\begin{array}{l}\text { United } \\
\text { Kingdom } \\
\text { Colombia } \\
\text { Ecuador } \\
\text { India }\end{array}$ & $\begin{array}{l}\text { London } \\
\text { Bogotá } \\
\text { Guayaquil } \\
\text { Chennai }\end{array}$ & $\begin{array}{l}\text { Regional } \\
\text { (Basin level) }\end{array}$ & Global & Academic and research bodies \\
\hline 22 & India & Nagpur City & Municipality & $\begin{array}{l}\text { Global } \\
\text { National }\end{array}$ & $\begin{array}{l}\text { Public authorities } \\
\text { Civil society } \\
\text { Academic and research bodies } \\
\text { Water-related actors } \\
\text { Industry, business and private } \\
\text { sector }\end{array}$ \\
\hline 23 & Iran & & $\begin{array}{l}\text { Regional } \\
\text { (Basin level) }\end{array}$ & & Academic and research bodies \\
\hline 24 & China & Shanghai & $\begin{array}{l}\text { Site } \\
\text { Other }\end{array}$ & & \\
\hline 25 & China & Jiangsu & $\begin{array}{l}\text { Regional } \\
\text { (Basin level) } \\
\text { Other }\end{array}$ & National & $\begin{array}{l}\text { Public authorities } \\
\text { Academic and research bodies } \\
\text { Water-related actors }\end{array}$ \\
\hline
\end{tabular}


Table A7. Cont.

\begin{tabular}{|c|c|c|c|c|c|}
\hline Code & Country & Location & Spatial & $\begin{array}{l}\text { Policy } \\
\text { Instruments }\end{array}$ & Actors \\
\hline 26 & China & - & $\begin{array}{l}\text { Regional } \\
\text { (Basin level) } \\
\text { National }\end{array}$ & Global & $\begin{array}{l}\text { Academic and research bodies } \\
\text { Water-related actors } \\
\text { Industry, business and private } \\
\text { sector }\end{array}$ \\
\hline 27 & $\begin{array}{l}\text { Cambodia } \\
\text { Indonesia } \\
\text { Lao PDR } \\
\text { Myanmar } \\
\text { Timor } \\
\text { Leste } \\
\text { Vietnam }\end{array}$ & - & Metropolitan Area & Global & $\begin{array}{l}\text { Academic and research bodies } \\
\text { Water-related actors }\end{array}$ \\
\hline 28 & Bolivia & $\begin{array}{l}\text { Santa Cruz } \\
\text { de la Sierra }\end{array}$ & $\begin{array}{l}\text { Municipality } \\
\text { Regional } \\
\text { (Basin level) }\end{array}$ & Municipal & $\begin{array}{l}\text { Public authorities } \\
\text { Civil society } \\
\text { Academic and research bodies }\end{array}$ \\
\hline 29 & Canada & - & $\begin{array}{l}\text { Municipality } \\
\text { Metropolitan Area }\end{array}$ & Municipal & $\begin{array}{l}\text { Public authorities } \\
\text { Civil society }\end{array}$ \\
\hline 30 & $\begin{array}{l}\text { United } \\
\text { States }\end{array}$ & Texas & Municipality & $\begin{array}{l}\text { Regional } \\
\text { Municipal } \\
\text { Local }\end{array}$ & \\
\hline 31 & $\begin{array}{l}\text { United } \\
\text { States } \\
\text { Ethiopia }\end{array}$ & $\begin{array}{l}\text { Detroit } \\
\text { Addis Ababa }\end{array}$ & $\begin{array}{l}\text { Site } \\
\text { Municipality } \\
\text { Regional } \\
\text { (Basin level) }\end{array}$ & & Academic and research bodies \\
\hline 32 & $\begin{array}{l}\text { Ethiopia } \\
\text { Tanzania }\end{array}$ & $\begin{array}{l}\text { Addis Ababa } \\
\text { Dar es } \\
\text { Salaam }\end{array}$ & $\begin{array}{l}\text { Neighborhood } \\
\text { Municipality }\end{array}$ & & $\begin{array}{l}\text { Public authorities } \\
\text { Civil society } \\
\text { Water-related actors }\end{array}$ \\
\hline 33 & Kenia & Nairobi & $\begin{array}{l}\text { Site } \\
\text { Neighborhood }\end{array}$ & & $\begin{array}{l}\text { Public authorities } \\
\text { Civil society } \\
\text { Public authorities }\end{array}$ \\
\hline 34 & Australia & Melbourne & & Municipal & $\begin{array}{l}\text { Civil society } \\
\text { Water-related actors }\end{array}$ \\
\hline 35 & Vanuatu & Port Vila & $\begin{array}{l}\text { Neighborhood } \\
\text { Regional } \\
\text { (Basin level) }\end{array}$ & Regional & $\begin{array}{l}\text { Public authorities } \\
\text { Civil society }\end{array}$ \\
\hline
\end{tabular}

\section{References}

1. Escobedo, F.J.; Giannico, V.; Jim, C.Y.; Sanesi, G.; Lafortezza, R. Urban forests, ecosystem services, green infrastructure and nature-based solutions: Nexus or evolving metaphors? Urban For. Urban Green. 2019, 37, 3-12. [CrossRef]

2. Wandl, D.I.A.; Nadin, V.; Zonneveld, W.; Rooij, R. Beyond urban-rural classifications: Characterising and mapping territories-in-between across Europe. Landsc. Urban Plan. 2014, 130, 50-63. [CrossRef]

3. Bauduceau, N.; Berry, P.; Cecchi, C.; Elmqvist, T.; Fernández, M.; Hartig, T.; Krull, W.; Mayerhofer, E.; Sandra, N.; Noring, L.; et al. Towards an EU Research and Innovation Policy Agenda for Nature-Based Solutions $\mathcal{E}$ Re-Naturing Cities: Final Report of the Horizon 2020 Expert Group on Nature-Based Solutions and Re-Naturing Cities; Publications Office of the EU: Luxembourg, 2015; 76p. [CrossRef]

4. Hanson, H.I.; Wickenberg, B.; Alkan Olsson, J. Working on the boundaries-How do science use and interpret the nature-based solution concept? Land Use Policy 2019, 104302. [CrossRef]

5. Kim, J. Subdivision design and landscape structure: Case study of The Woodlands, Texas, US. Urban For. Urban Green. 2019, 38, 232-241. [CrossRef]

6. Furlong, C.; Phelan, K.; Dodson, J. The role of water utilities in urban greening: A case study of Melbourne, Australia. Util. Policy 2018, 53, 25-31. [CrossRef]

7. La Rosa, D.; Pappalardo, V. Planning for spatial equity-A performance based approach for sustainable urban drainage systems. Sustain. Cities Soc. 2020, 53. [CrossRef] 
8. Säumel, I.; Reddy, S.E.; Wachtel, T. Edible city solutions-one step further to foster social resilience through enhanced socio-cultural ecosystem services in cities. Sustainability 2019, 11, 972. [CrossRef]

9. Dorst, H.; van der Jagt, A.; Raven, R.; Runhaar, H. Urban greening through nature-based solutions - Key characteristics of an emerging concept. Sustain. Cities Soc. 2019, 49, 101620. [CrossRef]

10. Cohen-Shacham, E.; Walters, G.; Janzen, C.; Maginnis, S. (Eds.) Nature-Based Solutions to Address Global Societal Challenges; IUCN: Gland, Switzaerland, 2016; Volume xiii.

11. Albert, C.; Schröter, B.; Haase, D.; Brillinger, M.; Henze, J.; Herrmann, S.; Gottwald, S.; Guerrero, P.; Nicolas, C.; Matzdorf, B. Addressing societal challenges through nature-based solutions: How can landscape planning and governance research contribute? Landsc. Urban Plan. 2019, 182, 12-21. [CrossRef]

12. Dallimer, M.; Martin-Ortega, J.; Rendon, O.; Afionis, S.; Bark, R.; Gordon, I.J.; Paavola, J. Taking stock of the empirical evidence on the insurance value of ecosystems. Ecol. Econ. 2020, 167. [CrossRef]

13. Dhyani, S.; Lahoti, S.; Khare, S.; Pujari, P.; Verma, P. Ecosystem based Disaster Risk Reduction approaches (EbDRR) as a prerequisite for inclusive urban transformation of Nagpur City, India. Int. J. Disaster Risk Reduct. 2018, 32, 95-105. [CrossRef]

14. Gómez Martín, E.; Máñez Costa, M.; Schwerdtner Máñez, K. An operationalized classification of Nature Based Solutions for water-related hazards: From theory to practice. Ecol. Econ. 2020, 167. [CrossRef]

15. Loiseau, E.; Saikku, L.; Antikainen, R.; Droste, N.; Hansjürgens, B.; Pitkänen, K.; Leskinen, P.; Kuikman, P.; Thomsen, M. Green economy and related concepts: An overview. J. Clean. Prod. 2016, 139, 361-371. [CrossRef]

16. Kabisch, N.; Frantzeskaki, N.; Pauleit, S.; Naumann, S.; Davis, M.; Artmann, M.; Haase, D.; Knapp, S.; Korn, H.; Stadler, J.; et al. Nature-based solutions to climate change mitigation and adaptation in urban areas: Perspectives on indicators, knowledge gaps, barriers, and opportunities for action. Ecol. Soc. 2016, 21, art39. [CrossRef]

17. Pagano, A.; Pluchinotta, I.; Pengal, P.; Cokan, B.; Giordano, R. Engaging stakeholders in the assessment of NBS effectiveness in flood risk reduction: A participatory System Dynamics Model for benefits and co-benefits evaluation. Sci. Total Environ. 2019, 690, 543-555. [CrossRef] [PubMed]

18. Ronchi, S.; Arcidiacono, A.; Pogliani, L. Integrating green infrastructure into spatial planning regulations to improve the performance of urban ecosystems. Insights from an Italian case study. Sustain. Cities Soc. 2020, 53. [CrossRef]

19. Shaw, B.J.; van Vliet, J.; Verburg, P.H. The peri-urbanization of Europe: A systematic review of a multifaceted process. Landsc. Urban Plan. 2020, 196. [CrossRef]

20. Wandl, A.; Magoni, M. Sustainable Planning of Peri-Urban Areas: Introduction to the Special Issue. Plan. Pract. Res. 2017, 32, 1-3. [CrossRef]

21. Mortoja, M.G.; Yigitcanlar, T.; Mayere, S. What is the most suitable methodological approach to demarcate peri-urban areas? A systematic review of the literature. Land Use Policy 2020, 95, 104601. [CrossRef]

22. Arabameri, A.; Rezaei, K.; Cerdà, A.; Conoscenti, C.; Kalantari, Z. A comparison of statistical methods and multi-criteria decision making to map flood hazard susceptibility in Northern Iran. Sci. Total Environ. 2019, 660, 443-458. [CrossRef]

23. Gunnell, K.; Mulligan, M.; Francis, R.A.; Hole, D.G. Evaluating natural infrastructure for flood management within the watersheds of selected global cities. Sci. Total Environ. 2019, 670, 411-424. [CrossRef] [PubMed]

24. Reynaud, A.; Lanzanova, D.; Liquete, C.; Grizzetti, B. Going green? Ex-post valuation of a multipurpose water infrastructure in Northern Italy. Ecosyst. Serv. 2017, 27, 70-81. [CrossRef] [PubMed]

25. Tomao, A.; Quatrini, V.; Corona, P.; Ferrara, A.; Lafortezza, R.; Salvati, L. Resilient landscapes in Mediterranean urban areas: Understanding factors influencing forest trends. Environ. Res. 2017, 156, 1-9. [CrossRef]

26. Bricker, S.H.; Banks, V.J.; Galik, G.; Tapete, D.; Jones, R. Accounting for groundwater in future city visions. Land Use Policy 2017, 69, 618-630. [CrossRef]

27. Capotorti, G.; De Lazzari, V.; Ortí, M.A. Local scale prioritisation of green infrastructure for enhancing biodiversity in Peri-Urban agroecosystems: A multi-step process applied in the Metropolitan City of Rome (Italy). Sustainability 2019, 11, 3322. [CrossRef]

28. Hazbavi, Z.; Keesstra, S.D.; Nunes, J.P.; Baartman, J.E.M.; Gholamalifard, M.; Sadeghi, S.H. Health comparative comprehensive assessment of watersheds with different climates. Ecol. Indic. 2018, 93, 781-790. [CrossRef] 
29. Herslund, L.; Mguni, P. Examining urban water management practices—Challenges and possibilities for transitions to sustainable urban water management in Sub-Saharan cities. Sustain. Cities Soc. 2019, 48, 101573. [CrossRef]

30. Jia, X.; O'Connor, D.; Hou, D.; Jin, Y.; Li, G.; Zheng, C.; Ok, Y.S.; Tsang, D.C.W.; Luo, J. Groundwater depletion and contamination: Spatial distribution of groundwater resources sustainability in China. Sci. Total Environ. 2019, 672, 551-562. [CrossRef]

31. Mulligan, J.; Bukachi, V.; Clause, J.C.; Jewell, R.; Kirimi, F.; Odbert, C. Hybrid infrastructures, hybrid governance: New evidence from Nairobi (Kenya) on green-blue-grey infrastructure in informal settlements: "Urban hydroclimatic risks in the 21st century: Integrating engineering, natural, physical and social sciences to build. Anthropocene 2020, 29. [CrossRef]

32. Pedersen Zari, M.; Blaschke, P.M.; Jackson, B.; Komugabe-Dixson, A.; Livesey, C.; Loubser, D.I.; Martinez-Almoyna Gual, C.; Maxwell, D.; Rastandeh, A.; Renwick, J.; et al. Devising urban ecosystem-based adaptation (EbA) projects with developing nations: A case study of Port Vila, Vanuatu. Ocean Coast. Manag. 2020, 184. [CrossRef]

33. Brunetta, G.; Salata, S. Mapping urban resilience for spatial planning-A first attempt to measure the vulnerability of the system. Sustainability 2019, 11, 2331. [CrossRef]

34. Thompson, K.; Sherren, K.; Duinker, P.N. The use of ecosystem services concepts in Canadian municipal plans. Ecosyst. Serv. 2019, 38, 100950. [CrossRef]

35. Belčáková, I.; Świader, M.; Bartyna-Zielińska, M. The green infrastructure in cities as a tool for climate change adaptation and mitigation: Slovakian and polish experiences. Atmosphere 2019, 10, 552. [CrossRef]

36. Fung, C.K.W.; Jim, C.Y. Influence of blue infrastructure on lawn thermal microclimate in a subtropical green space. Sustain. Cities Soc. 2020, 52. [CrossRef]

37. Marando, F.; Salvatori, E.; Sebastiani, A.; Fusaro, L.; Manes, F. Regulating Ecosystem Services and Green Infrastructure: Assessment of Urban Heat Island effect mitigation in the Municipality of Rome, Italy. Ecol. Modell. 2019, 392, 92-102. [CrossRef]

38. Carrard, N.; Foster, T.; Willetts, J. Groundwater as a source of drinking water in southeast Asia and the Pacific: A multi-country review of current reliance and resource concerns. Water 2019, 11, 1605. [CrossRef]

39. Castelli, G.; Foderi, C.; Guzman, B.H.; Ossoli, L.; Kempff, Y.; Bresci, E.; Salbitano, F. Planting waterscapes: Green infrastructures, landscape and hydrological modeling for the future of Santa Cruz de la Sierra, Bolivia. Forests 2017, 8, 437. [CrossRef]

40. Yang, C.; Nan, J.; Yu, H.; Li, J. Embedded reservoir and constructed wetland for drinking water source protection: Effects on nutrient removal and phytoplankton succession. J. Environ. Sci. (China) 2020, 87, 260-271. [CrossRef]

41. Belmeziti, A.; Cherqui, F.; Kaufmann, B. Improving the multi-functionality of urban green spaces: Relations between components of green spaces and urban services. Sustain. Cities Soc. 2018, 43, 1-10. [CrossRef]

42. Langemeyer, J.; Wedgwood, D.; McPhearson, T.; Baró, F.; Madsen, A.L.; Barton, D.N. Creating urban green infrastructure where it is needed-A spatial ecosystem service-based decision analysis of green roofs in Barcelona. Sci. Total Environ. 2020, 707. [CrossRef]

43. McFarland, A.R.; Larsen, L.; Yeshitela, K.; Engida, A.N.; Love, N.G. Guide for using green infrastructure in urban environments for stormwater management. Environ. Sci. Water Res. Technol. 2019, 5, 643-659. [CrossRef]

44. Liquete, C.; Udias, A.; Conte, G.; Grizzetti, B.; Masi, F. Integrated valuation of a nature-based solution for water pollution control. Highlighting hidden benefits. Ecosyst. Serv. 2016, 22, 392-401. [CrossRef]

45. Beery, T.H.; Raymond, C.M.; Kyttä, M.; Olafsson, A.S.; Plieninger, T.; Sandberg, M.; Stenseke, M.; Tengö, M.; Jönsson, K.I. Fostering incidental experiences of nature through green infrastructure planning. Ambio 2017, 46, 717-730. [CrossRef] [PubMed]

46. Cortinovis, C.; Zulian, G.; Geneletti, D. Assessing nature-based recreation to support urban green infrastructure planning in Trento (Italy). Land 2018, 7, 112. [CrossRef]

47. Jerome, G.; Mell, I.; Shaw, D. Re-defining the characteristics of environmental volunteering: Creating a typology of community-scale green infrastructure. Environ. Res. 2017, 158, 399-408. [CrossRef]

48. Riegels, N.; Lynggaard-Jensen, A.; Krogsgaard Jensen, J.; Gerner, N.V.; Anzaldua, G.; Mark, O.; Butts, M.; Birk, S. Making the ecosystem services approach operational: A case study application to the Aarhus River, Denmark. Sci. Total Environ. 2020, 707. [CrossRef] 
49. Fan, P.; Ouyang, Z.; Basnou, C.; Pino, J.; Park, H.; Chen, J. Nature-based solutions for urban landscapes under post-industrialization and globalization: Barcelona versus Shanghai. Environ. Res. 2017, 156, $272-283$. [CrossRef]

50. Sahani, J.; Kumar, P.; Debele, S.; Spyrou, C.; Loupis, M.; Aragão, L.; Porcù, F.; Shah, M.A.R.; Di Sabatino, S. Hydro-meteorological risk assessment methods and management by nature-based solutions. Sci. Total Environ. 2019, 696. [CrossRef]

51. Grizzetti, B.; Lanzanova, D.; Liquete, C.; Reynaud, A.; Cardoso, A.C.C. Assessing water ecosystem services for water resource management. Environ. Sci. Policy. 2016, 61, 194-203. [CrossRef]

52. Raymond, C.M.; Frantzeskaki, N.; Kabisch, N.; Berry, P.; Breil, M.; Nita, M.R.; Geneletti, D.; Calfapietra, C. A framework for assessing and implementing the co-benefits of nature-based solutions in urban areas. Environ. Sci. Policy. 2017, 77, 15-24. [CrossRef]

Publisher's Note: MDPI stays neutral with regard to jurisdictional claims in published maps and institutional affiliations.

(C) 2020 by the authors. Licensee MDPI, Basel, Switzerland. This article is an open access article distributed under the terms and conditions of the Creative Commons Attribution (CC BY) license (http://creativecommons.org/licenses/by/4.0/). 